\title{
Atmospheric nitric oxide and ozone at the WAIS Divide deep coring site: a discussion of local sources and transport in West Antarctica
}

\author{
S. Masclin ${ }^{1}$, M. M. Frey ${ }^{2,1}$, W. F. Rogge ${ }^{1,3}$, and R. C. Bales ${ }^{1,3}$ \\ ${ }^{1}$ Environmental Systems, University of California, Merced, California, USA \\ ${ }^{2}$ British Antarctic Survey, Natural Environment Research Council, Cambridge, UK \\ ${ }^{3}$ Sierra Nevada Research Institute, University of California, Merced, California, USA
}

Correspondence to: S. Masclin (smasclin@ucmerced.edu)

Received: 18 December 2012 - Published in Atmos. Chem. Phys. Discuss.: 14 March 2013

Revised: 20 June 2013 - Accepted: 18 July 2013 - Published: 5 September 2013

\begin{abstract}
The first measurements of atmospheric nitric oxide (NO) along with observations of ozone $\left(\mathrm{O}_{3}\right)$, hydroperoxides $\left(\mathrm{H}_{2} \mathrm{O}_{2}\right.$ and $\left.\mathrm{MHP}\right)$ and snow nitrate $\left(\mathrm{NO}_{3}^{-}\right)$on the West Antarctic Ice Sheet (WAIS) were carried out at the WAIS Divide deep ice-coring site between 10 December 2008 and 11 January 2009. Average $\pm 1 \sigma$ mixing ratios of NO were $19 \pm 31 \mathrm{pptv}$ and confirmed prior model estimates for the summer boundary layer above WAIS. Mean $\pm 1 \sigma$ mixing ratios of $\mathrm{O}_{3}$ of $14 \pm 4 \mathrm{ppbv}$ were in the range of previous measurements from overland traverses across WAIS during summer, while average $\pm 1 \sigma$ concentrations of $\mathrm{H}_{2} \mathrm{O}_{2}$ and MHP revealed higher levels with mixing ratios of $743 \pm 362$ and $519 \pm 238$ pptv, respectively.
\end{abstract}

An upper limit for daily average $\mathrm{NO}_{2}$ and NO emission fluxes from snow of $8.6 \times 10^{8}$ and $33.9 \times 10^{8}$ molecule $\mathrm{cm}^{-2} \mathrm{~s}^{-1}$, respectively, were estimated based on photolysis of measured $\mathrm{NO}_{3}^{-}$and nitrite $\left(\mathrm{NO}_{2}^{-}\right)$in the surface snowpack. The resulting high $\mathrm{NO}_{\mathrm{x}}$ emission flux may explain the little preservation of $\mathrm{NO}_{3}^{-}$ in snow $(\sim 30 \%)$ when compared to Summit, Greenland (75-93\%). Assuming rapid and complete mixing into the overlying atmosphere, and steady state of $\mathrm{NO}_{\mathrm{x}}$, these snow emissions are equivalent to an average (range) production of atmospheric $\mathrm{NO}_{\mathrm{x}}$ of $30(21-566) \mathrm{pptvh}^{-1}$ for a typical atmospheric boundary-layer depth of 250 (354-13) $\mathrm{m}$. These upper bounds indicate that local emissions from the snowpack are a significant source of short-lived nitrogen oxides above the inner WAIS.

The net $\mathrm{O}_{3}$ production of $0.8 \mathrm{ppbv}^{-1 a y^{-1}}$ triggered with NO higher than 2 pptv is too small to explain the observed $\mathrm{O}_{3}$ variability. Thus, the origins of the air masses reaching
WAIS Divide during this campaign were investigated with a 4-day back-trajectory analysis every $4 \mathrm{~h}$. The resulting 168 back trajectories revealed that in $75 \%$ of all runs air originated from the Antarctic coastal slopes (58\%) and the inner WAIS $(17 \%)$. For these air sources $\mathrm{O}_{3}$ levels were on average $13 \pm 3$ ppbv. The remaining $25 \%$ are katabatic outflows from the East Antarctic Plateau above $2500 \mathrm{~m}$. When nearsurface air from the East Antarctic Plateau reaches WAIS Divide through a rapid transport of less than 3 days, $\mathrm{O}_{3}$ levels are on average $19 \pm 4 \mathrm{ppbv}$ with maximum mixing ratios of $30 \mathrm{ppbv}$. Episodes of elevated ozone at WAIS Divide are therefore linked to air mass export off the East Antarctic Plateau, demonstrating that outflows from the highly oxidizing summer atmospheric boundary layer in the interior of the continent can episodically raise the mixing ratios of longlived atmospheric chemical species such as $\mathrm{O}_{3}$ and enhance the oxidative capacity of the atmosphere above WAIS.

\section{Introduction}

Over the last decade, a large number of field and lab studies have provided evidence of the importance of snow photochemistry on the chemical composition of air above snowcovered surfaces in the polar and mid-latitudes (Grannas et al., 2007, and references therein). The upper snowpack is seen not only as a chemical reservoir but as a chemical reactor. Trace gases emitted by the snowpack include hydrogen peroxide $\left(\mathrm{H}_{2} \mathrm{O}_{2}\right)$, formaldehyde $\left(\mathrm{CH}_{2} \mathrm{O}\right)$ and nitrogen oxides $\left(\mathrm{NO}_{\mathrm{x}}=\mathrm{NO}+\mathrm{NO}_{2}\right)$, and increase the oxidizing potential of the atmospheric boundary layer through production of 
the hydroxyl radical $(\mathrm{OH})$ and ozone $\left(\mathrm{O}_{3}\right)$ (Grannas et al., 2007; Thomas et al., 2012). Measurements of atmospheric and snow concentrations and also fluxes from snow surfaces indicate that the polar snowpack emits $\mathrm{NO}_{\mathrm{x}}$ mainly through the photolysis of nitrate $\left(\mathrm{NO}_{3}^{-}\right)$in near-surface snow (Grannas et al., 2007; Bauguitte et al., 2012; Frey et al., 2013). Snowpack emissions of $\mathrm{NO}_{\mathrm{x}}$ can contribute significantly to the $\mathrm{NO}_{\mathrm{y}}\left(\mathrm{NO}_{\mathrm{x}}+\right.$ other oxidized nitrogen species) budget above snow, as observed in continental and coastal Antarctica (Jones et al., 2000; Frey et al., 2013). Bauguitte et al. (2012) reached a similar conclusion at Halley station by highlighting that halogen chemistry over the Antarctic coast controls the lifetime of $\mathrm{NO}_{\mathrm{x}}$ species and reduces the nitric oxide (NO) mixing ratios. When atmospheric turbulence is low or atmospheric boundary layer depths are shallow, these emissions contribute to high $\mathrm{NO}_{\mathrm{x}}$ levels, several hundred pptv, as observed at South Pole and over the East Antarctic Plateau (Davis et al., 2004, 2008; Slusher et al., 2010; Frey et al., 2013). Chen et al. (2004) and Mauldin et al. (2004) showed that at South Pole these high levels of $\mathrm{NO}_{\mathrm{x}}$ shift the $\mathrm{HO}_{\mathrm{x}}\left(\mathrm{OH}+\mathrm{HO}_{2}\right)$ partitioning towards $\mathrm{OH}$ :

$\mathrm{NO}+\mathrm{HO}_{2} \rightarrow \mathrm{NO}_{2}+\mathrm{OH}$.

$\mathrm{NO}_{\mathrm{x}}$ emissions from snow can also lead to net production of $\mathrm{O}_{3}$ over the East Antarctic Plateau (Helmig et al., 2008a, and references therein), and thereby shift $\mathrm{HO}_{\mathrm{x}}$ partitioning of the overlying atmosphere.

Above the West Antarctic Ice Sheet (WAIS), enhanced snowpack emissions of $\mathrm{NO}_{\mathrm{x}}$ associated with events of stratospheric $\mathrm{O}_{3}$ depletion may lower the formation rate of atmospheric $\mathrm{H}_{2} \mathrm{O}_{2}$ (Frey et al., 2005). Photochemical modeling suggests that atmospheric $\mathrm{H}_{2} \mathrm{O}_{2}$ is sensitive to the NO background, opening up the possibility of constraining past $\mathrm{NO}_{\mathrm{x}}$ and $\mathrm{OH}$ levels using the $\mathrm{H}_{2} \mathrm{O}_{2}$ ice-core record (Frey et al., 2005, 2006). Therefore, investigation of the current atmospheric boundary-layer photochemistry at a WAIS ice-core drilling site is essential to interpret ice-core records of photochemically active species such as $\mathrm{H}_{2} \mathrm{O}_{2}$ and $\mathrm{NO}_{3}^{-}$. This can also provide information regarding the contribution of air advection from the East Antarctic Plateau to levels of oxidants above WAIS, similar to Legrand et al. (2009) who observed outflows from the Antarctic Plateau increasing $\mathrm{O}_{3}$ concentrations at the East Antarctic coastal site Dumont D'Urville.

So far, atmospheric-sampling campaigns in the Antarctic have taken place at existing stations on the coast (Dumont D'Urville, Halley, Neumayer) and on the East Antarctic Plateau (South Pole, Dome C). Only recent airborne campaigns (Eisele and Davis, 2008; Slusher et al., 2010) or scientific overland traverses (Frey et al., 2005) provided information on the composition of the lower atmosphere across the interior of the continent. Thus, spatial data coverage of the lower atmosphere in Antarctica is still sparse and little is known about the variability of $\mathrm{O}_{3}$ and its precursors above WAIS. For example, the first ground-based measurements across WAIS lasting several days included at- mospheric records of $\mathrm{H}_{2} \mathrm{O}_{2}$, methyl hydroperoxide (MHP), $\mathrm{CH}_{2} \mathrm{O}, \mathrm{O}_{3}$ but not $\mathrm{NO}_{\mathrm{x}}$ (Frey et al., 2005).

The current study includes multi-week first observations of $\mathrm{NO}$ and complementary measurements of atmospheric $\mathrm{O}_{3}$, $\mathrm{H}_{2} \mathrm{O}_{2}$, MHP and of surface-snow $\mathrm{H}_{2} \mathrm{O}_{2}, \mathrm{NO}_{3}^{-}$and nitrite $\left(\mathrm{NO}_{2}^{-}\right)$in the WAIS region. The aims were to determine the summer composition of the lower atmosphere in the interior of West Antarctica and the relative importance of local production versus air mass transport on the local atmospheric budgets of $\mathrm{NO}_{\mathrm{x}}$ and $\mathrm{O}_{3}$.

\section{Methods}

From 10 December 2008 to 11 January 2009, atmospheric concentrations of $\mathrm{NO}$ and $\mathrm{O}_{3}$ were continuously measured at WAIS Divide (local time: LT $=\mathrm{UTC}-07: 30$ ). Mixing ratios of ROOH $\left(\mathrm{H}_{2} \mathrm{O}_{2}\right.$ and MHP) were recorded between 31 December 2008 to 7 January 2009. Snow samples were collected daily from the surface and weekly from $30 \mathrm{~cm}$ snow pits for chemical analysis of $\mathrm{NO}_{3}^{-}, \mathrm{NO}_{2}^{-}$and $\mathrm{H}_{2} \mathrm{O}_{2}$.

Atmospheric sampling took place $5 \mathrm{~km} \mathrm{NW}$ of the WAIS Divide drilling camp $\left(79.467^{\circ} \mathrm{S}, 112.085^{\circ} \mathrm{W}\right.$, 1766 m a.m.s.l., http://www.waisdivide.unh.edu). All instruments were run out of a Polarhaven tent heated by a preway heater. Atmospheric measurements were made $1 \mathrm{~m}$ above the snow, $10 \mathrm{~m}$ upwind (prevailing winds from $\mathrm{NE}$ ) from the tent, with ambient air drawn through an insulated and heated PFA (1/4" I.D.) intake line (typically $1.4 \mathrm{STP}-\mathrm{L} \mathrm{min}^{-1}$ ) of $12 \mathrm{~m}$ for $\mathrm{ROOH}$, and of $20 \mathrm{~m}$ for $\mathrm{NO}$ and $\mathrm{O}_{3}$. In an attempt to minimize artifacts in our atmospheric records, the two generators ( 3.5 and $5 \mathrm{KW}$ ) that provided electricity to the lab were located about $30 \mathrm{~m}$ downwind from the sampling lines, and all activities around the site were restricted. However, the heater exhaust was located on the top of the Polarhaven tent.

\subsection{Atmospheric sampling}

NO was measured using a modified chemiluminescence instrument used previously at South Pole (Davis et al., 2001, 2004). NO mixing ratios recorded at $1 \mathrm{~Hz}$ were aggregated to $1 \mathrm{~min}$ averages. The limit of detection (LOD), defined as $2-\sigma$ of the background count rate, was 5 pptv. A two-minute background signal was monitored every $20 \mathrm{~min}$ and an automatic 4 min calibration was performed every $2 \mathrm{~h}$ by addition of a 2 ppmv NO standard. Due to late delivery of this NO gas standard to the site, calibration was only run during the last 3 days of the campaign. The instrument sensitivity remained fairly constant over the three days, with an average over 16 calibrations of $7.10 \pm 0.18 \mathrm{Hzptv}^{-1}$, similar to the preseason value of $7.00 \mathrm{Hzpptv}^{-1}$ determined in the lab. We therefore used the 3-day average value of these calibrations to process the overall dataset. NO spikes related to pollution from generators and heater exhaust were removed using a moving standard deviation filter with a maximum standard deviation 
of 30 (1.5 times the interquartile range of the dataset). This led to the removal of $25 \%$ from the raw NO record.

Surface $\mathrm{O}_{3}$ was monitored at $1 \mathrm{~min}$ resolution using a $2 \mathrm{~B}$ Technologies (Golden, Colorado) $\mathrm{O}_{3}$ monitor, model 205, similar to those previously used in the remote Antarctic such as on the ITASE traverses (Frey et al., 2005) and in an $\mathrm{O}_{3}$ monitoring network (Bauguitte et al., 2011). LOD was 1 ppbv.

Atmospheric $\mathrm{ROOH}$ were measured based on continuous scrubbing of sample air followed by separation in an HPLC column and fluorescence detection, described in detail by Frey et al. (2005, 2009a). The detector was calibrated 1-2 times per day with $\mathrm{H}_{2} \mathrm{O}_{2}$ solution and MHP standards synthesized in our lab following the protocol described by Frey et al. (2009a). The LOD, 2- $\sigma$ of the baseline, were $87 \mathrm{pptv}$ for $\mathrm{H}_{2} \mathrm{O}_{2}$ and $167 \mathrm{pptv}$ for MHP. Unexpected variations of the coil-scrubber temperatures may have caused higher LOD than those reported by Frey et al. $(2005,2009 a)$.

\subsection{Snow sampling}

All surface snow and snow pits were sampled in a $7200 \mathrm{~m}^{2}$ clean area upwind from the Polarhaven tent. The top $1 \mathrm{~cm}$ of the non-cohesive surface snow, referred to as the skin layer (Frey et al., 2009b; Erbland et al., 2013), was collected daily with a $10 \mathrm{~mL}$ glass test tube to assess temporal changes in snow chemistry. Twice during the campaign, the skin layer was sampled simultaneously at five different spots inside the clean area to assess possible local spatial variability of $\mathrm{NO}_{3}^{-}$, $\mathrm{NO}_{2}^{-}$and $\mathrm{H}_{2} \mathrm{O}_{2}$.

Weekly snow pits were sampled at $2 \mathrm{~cm}$ resolution to a depth of $30 \mathrm{~cm}$, covering the snowpack zone where $85 \%$ of $\mathrm{NO}_{3}^{-}$photolysis is expected to occur (France et al., 2011). Snowflakes were collected on aluminum foil during the only snow precipitation event observed during the campaign, on 12 December 2008.

All snow samples were collected in $100 \mathrm{~mL}$ SCHOTT bottles and kept frozen during storage and transport until analysis 14 months later. The analysis involved melting the snow 1 hour before injecting the sample into a self-built continuous flow analysis (CFA) system, as described by Frey et al. (2006). The LOD, defined as $3 \sigma$ of the baseline, was 0.4 ppbw for $\mathrm{NO}_{3}^{-}, \mathrm{NO}_{2}^{-}$and $\mathrm{H}_{2} \mathrm{O}_{2}$. Only values above $\mathrm{LOD}$ were used for further calculations. Some loss of $\mathrm{NO}_{2}^{-}$in the samples may have occurred between the time of collection and analysis, as Takenaka and Bandow (2007) and O'Driscoll et al. (2012) showed that $\mathrm{NO}_{2}^{-}$may be oxidized during freezing and storage.

\section{Results}

\subsection{Atmospheric concentrations}

The average $\pm 1 \sigma$ (median) of NO over the campaign was $19 \pm 31$ (10) pptv (Table 1). Some noise remained in the NO dataset after filtering; however, the $4 \mathrm{~h}$ running median (Fig. 1a) shows very little change in the overall trend of the data due to filtering, with the median value after filtering similar to that of the raw dataset (6 pptv). One-minute data did not exhibit any clear diel cycle (Fig. 1), but $1 \mathrm{~h}$ binned data centered on each hour for the measurement period revealed a diel cycle that can be interpreted with the variations of the average solar elevation angle (Fig. 2b). NO mixing ratios increased at 07:00-08:00 LT with a maximum rise of $36 \%$ from the daily median of $10 \mathrm{pptv}$. A decrease was observed afterwards and followed by a second increase of $20 \%$ above the median value at 19:00 LT. These peaks in NO occurred as solar elevation angle increased and decreased, with lower values of $\mathrm{NO}$ at the maxima and minima of solar elevation angle.

Average $\pm 1 \sigma$ (median) mixing ratios of $\mathrm{O}_{3}$ at WAIS Divide were $14 \pm 4$ (13) ppbv (Table 1). The mean is two thirds of the $20 \pm 2 \mathrm{ppbv}$ average mixing ratio observed at Byrd Station in summer 2002, but is in the range of values from previous measurements between $79.06^{\circ} \mathrm{S}$ and $85.00^{\circ} \mathrm{S}$ above the WAIS (Frey et al., 2005) (Fig. 3). Two events of elevated $\mathrm{O}_{3}$ levels were recorded between 24 and 25 December, and between 27 and 29 December, with concentrations in the range of 20 to $30 \mathrm{ppbv}$ (Fig. 1). Concentrations above 25 ppbv were only observed for winds blowing from ENE to SWS. This $135^{\circ}$ sector represents $67 \%$ of all the wind directions observed during the field campaign (Fig. 4). The hourly binned $\mathrm{O}_{3}$ data (Fig. 2b) show a small diel cycle in phase with solar elevation angle and wind speed. The mixing ratios rose by $5 \%$ of the median value ( $13 \mathrm{ppbv}$ ) in the morning, reaching a maximum at 14:00 LT and dropping thereafter in the afternoon.

Concentrations of $\mathrm{H}_{2} \mathrm{O}_{2}$ and MHP were measured between 31 December 2008 and 5 January 2009 (Fig. 1). Averages $\pm 1 \sigma$ (medians) were $743 \pm 362(695)$ and $519 \pm 238$ (464) pptv for $\mathrm{H}_{2} \mathrm{O}_{2}$ and MHP, respectively. Our records are closer to values observed at West Antarctic sites below $1500 \mathrm{~m}$ a.m.s.l. and higher than measurements made in the surrounding area (Fig. 3), with mixing ratios of $\mathrm{H}_{2} \mathrm{O}_{2}$ that were twice those observed at Byrd station in late November 2002 (Table 1) (Frey et al., 2005). Average $\pm 1 \sigma$ (range) of the MHP: $\left(\mathrm{H}_{2} \mathrm{O}_{2}+\mathrm{MHP}\right)$ ratios were $0.42 \pm 0.10(0.12$ $0.76)$. These values are in the range of those previously recorded over WAIS (Frey et al., 2005). Binned values suggest, for both $\mathrm{H}_{2} \mathrm{O}_{2}$ and MHP, a diel cycle with respective maximum 44 and $37 \%$ above their medians (695 and 464 pptv) observed in the morning (Fig. 2c). 
Table 1. Averages $\pm 1 \sigma$ (medians) of atmospheric and snow concentrations of the chemical species observed at WAIS Divide and nearby sites.

\begin{tabular}{|c|c|c|c|c|c|c|c|}
\hline \multirow[t]{2}{*}{ Site } & \multicolumn{4}{|c|}{ atmospheric } & \multicolumn{3}{|c|}{ skin layer } \\
\hline & $\begin{array}{l}\text { NO } \\
\text { (pptv) }\end{array}$ & $\begin{array}{l}\mathrm{O}_{3} \\
\text { (ppbv) }\end{array}$ & $\begin{array}{l}\mathrm{H}_{2} \mathrm{O}_{2} \\
\text { (pptv) }\end{array}$ & $\begin{array}{l}\text { MHP } \\
\text { (pptv) }\end{array}$ & $\begin{array}{l}\mathrm{H}_{2} \mathrm{O}_{2} \\
\text { (ppbw) }\end{array}$ & $\begin{array}{l}\mathrm{NO}_{3}^{-} \\
\text {(ppbw) }\end{array}$ & $\begin{array}{l}\mathrm{NO}_{2}^{-} \\
\text {(ppbw) }\end{array}$ \\
\hline WAIS Divide & $\begin{array}{l}19 \pm 31 \\
(10)\end{array}$ & $\begin{array}{l}14 \pm 4 \\
(13)\end{array}$ & $\begin{array}{l}743 \pm 362 \\
(695)\end{array}$ & $\begin{array}{l}519 \pm 238 \\
(464)\end{array}$ & $\begin{array}{l}238 \pm 37 \\
(238)\end{array}$ & $\begin{array}{l}137 \pm 37 \\
(142)\end{array}$ & $\begin{array}{l}0.6 \pm 0.4 \\
(0.5)\end{array}$ \\
\hline ITASE $00-1^{\mathrm{a}}$ & - & - & $303 \pm 159$ & - & 175 & - & - \\
\hline Byrd $^{b}$ & $\begin{array}{l}10 \\
-\end{array}$ & $\begin{array}{l}20 \pm 2 \\
(20)\end{array}$ & $\begin{array}{l}364 \pm 138 \\
(348)\end{array}$ & $\begin{array}{l}422 \pm 162 \\
(411)\end{array}$ & $\begin{array}{l}25 \pm 4 \\
(25)\end{array}$ & - & - \\
\hline
\end{tabular}

a $79.38^{\circ} \mathrm{S}, 111.23^{\circ} \mathrm{W}, 1791 \mathrm{~m}$ a.m.s.l. (from Frey et al., 2005)

b $80.02^{\circ} \mathrm{S}, 119.60^{\circ} \mathrm{W}, 1537 \mathrm{~m}$ a.m.s.l. (from Frey et al., 2005); $\mathrm{NO}$ based on optimum model runs; atmospheric $\mathrm{H}_{2} \mathrm{O}_{2}$ from sampling at site RIDS-C $\left(80.00^{\circ} \mathrm{S}, 119.53^{\circ} \mathrm{W}, 1575 \mathrm{~m}\right.$ a.m.s.l. $) ; \mathrm{H}_{2} \mathrm{O}_{2}$ in snow from sampling at site RIDS-B in $1996\left(79.46^{\circ} \mathrm{S}, 118.04^{\circ} \mathrm{W}\right.$, $1650 \mathrm{~m}$ a.m.s.l.)

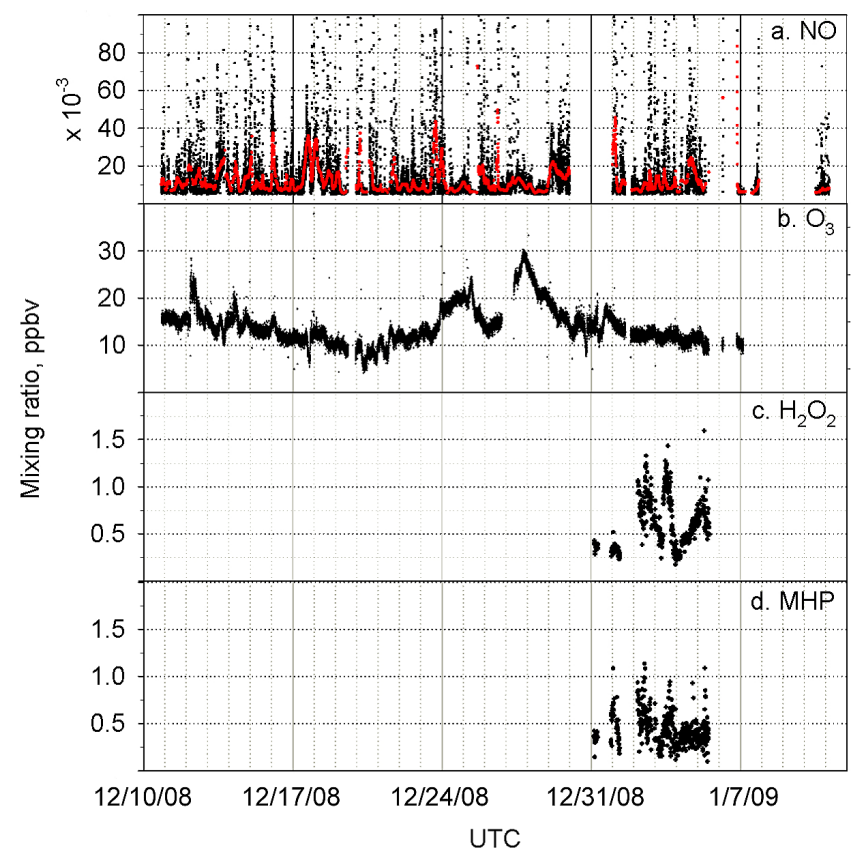

Fig. 1. Atmospheric mixing ratios of $\mathrm{NO}$ after filtering and $\mathrm{O}_{3}$ ( 1 min averages), and of $\mathrm{H}_{2} \mathrm{O}_{2}$ and MHP (10-minute averages) during austral summer 2008-2009 at WAIS Divide. The $4 \mathrm{~h}$ running median of NO is also shown (red symbols).

\subsection{Concentrations in snow}

Average $\pm 1 \sigma$ (median) concentrations of $\mathrm{NO}_{2}^{-}, \mathrm{NO}_{3}^{-}$and $\mathrm{H}_{2} \mathrm{O}_{2}$ in the skin layer at WAIS Divide were $0.6 \pm 0.4(0.5)$, $137 \pm 37$ (142) and $238 \pm 37$ (238) ppbw, respectively (Table 1). Daily concentrations of $\mathrm{NO}_{2}^{-}$in the skin layer showed a decrease of 30 pptw per day $\left(R^{2}=0.36\right)$ over the campaign (Fig. 5). This decrease represents a rate of $5 \%$ perday of the average concentration of $\mathrm{NO}_{2}^{-}$measured in all of the snowsurface samples. Unlike $\mathrm{NO}_{2}^{-}, \mathrm{NO}_{3}^{-}$and $\mathrm{H}_{2} \mathrm{O}_{2}$ exhibited some variation but no trend was observed for these species.

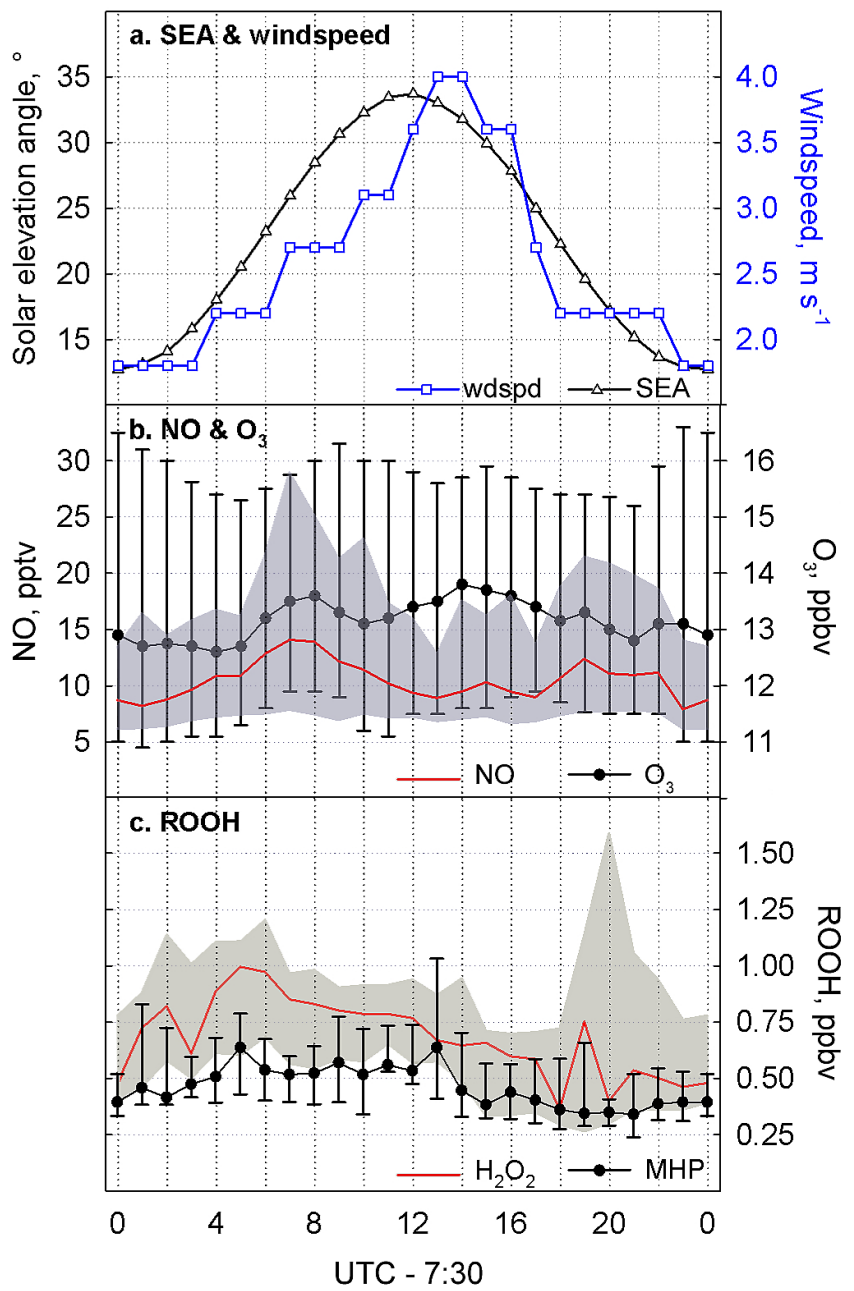

Fig. 2. Diel variation of (a) average solar elevation angle (SEA) and wind speed, (b) median $\mathrm{NO}$ (left axis) and $\mathrm{O}_{3}$ (right axis), and (c) median $\mathrm{H}_{2} \mathrm{O}_{2}$ and MHP. Symbols and lines are $1 \mathrm{~h}$ binned values centered on each hour; shaded area and error bars indicate the range between the first and third quartiles; local time is UTC - 07:30. 

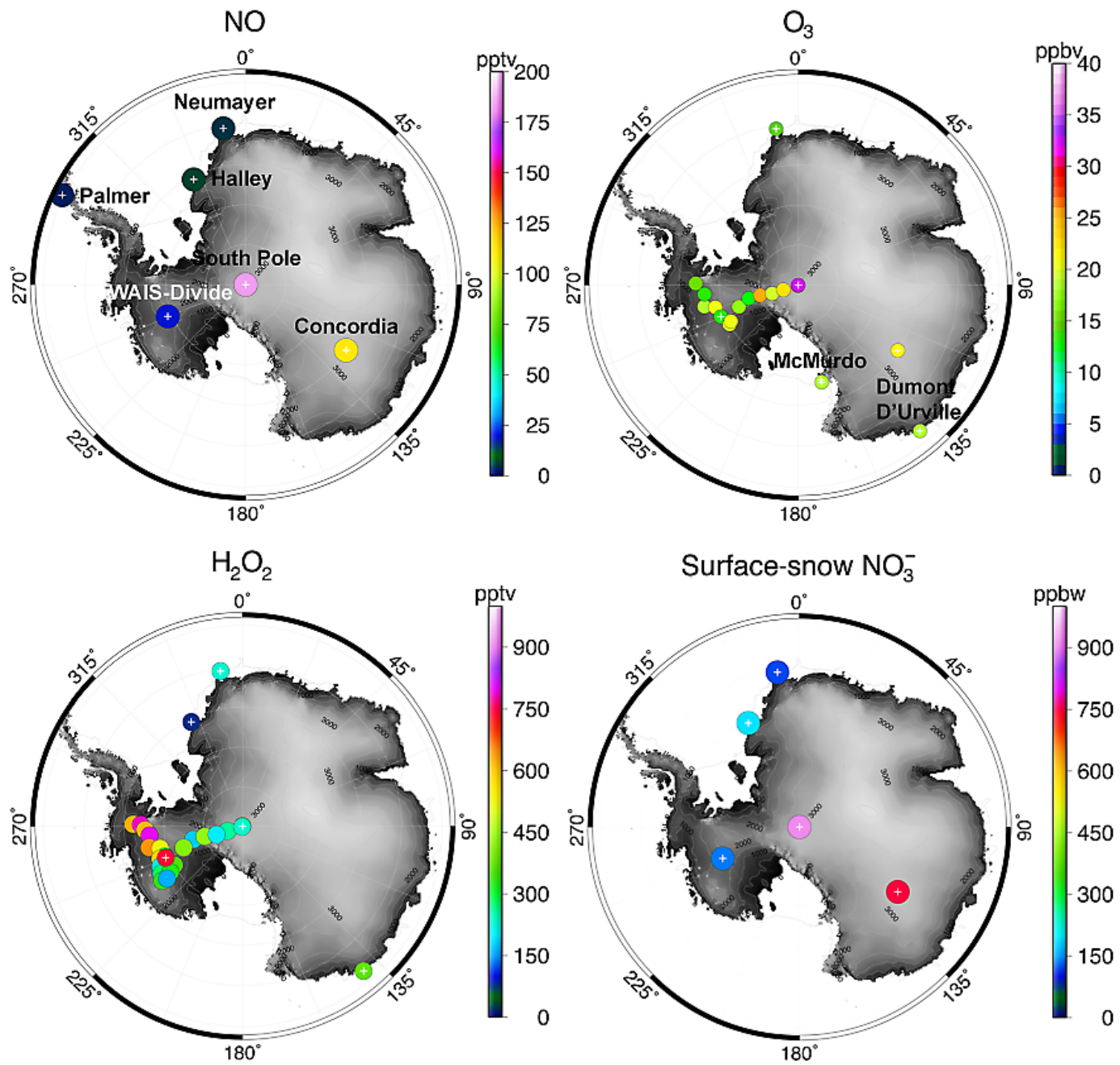

Fig. 3. Report of some previous Antarctic measurements of atmospheric $\mathrm{NO}$, surface $\mathrm{O}_{3}, \mathrm{H}_{2} \mathrm{O}_{2}$, plus $\mathrm{NO}_{3}^{-}$in surface snow. Data from Frey et al. (2013), Preunkert et al. (2012), Frey et al. (2009a), Legrand et al. (2009), Frey et al. (2005), Dibb et al. (2004), Davis et al. (2004), Rothlisberger et al. (2000), Jacobi et al. (2000), Jones et al. (1999), Mulvaney et al. (1998), Jefferson et al. (1998), NOAA/GMD, and AWI (http://ds.data.jma.go.jp/gmd/wdcgg/).

The coefficients of variation of concentrations of $\mathrm{NO}_{2}^{-}$, $\mathrm{NO}_{3}^{-}$and $\mathrm{H}_{2} \mathrm{O}_{2}$ in the skin layer are $49 \%, 26 \%$ and $17 \%$, respectively. The coefficients of variation for samples collected simultaneously on 1 and 8 January 2009 (Fig. 5) are $17 \%, 31 \%$ and $7 \%$ for $\mathrm{NO}_{2}^{-}, \mathrm{NO}_{3}^{-}$and $\mathrm{H}_{2} \mathrm{O}_{2}$, respectively. The similar coefficients of variation for $\mathrm{NO}_{3}^{-}$concentrations in snow imply that spatial variability contributes significantly to the overall variability and thus a temporal trend may be difficult to detect. For $\mathrm{NO}_{2}^{-}$and $\mathrm{H}_{2} \mathrm{O}_{2}$, the coefficients of temporal variability (49\% and $17 \%$, respectively) are more than double those calculated from spatial variability $(17 \%$ and $7 \%$, respectively). The variations of daily concentrations of $\mathrm{NO}_{2}^{-}$and $\mathrm{H}_{2} \mathrm{O}_{2}$ in near-surface snow may then be interpreted as temporal trends. Concentrations of $\mathrm{H}_{2} \mathrm{O}_{2}$ in the top $5-15 \mathrm{~cm}$ of the profile (Fig. 6) may also indicate a temporal trend; seasonal increase in concentrations measured over this period was apparent not only in the top $5 \mathrm{~cm}$ of snow, but also down to at least $15 \mathrm{~cm}$. Although there was no new snow accumulation during this period, there was wind redistribution and atmosphere-snow exchange of $\mathrm{H}_{2} \mathrm{O}_{2}$ and other atmospheric gas species, or nighttime deposition of fog.

The $30 \mathrm{~cm}$ deep profiles of $\mathrm{NO}_{2}^{-}, \mathrm{NO}_{3}^{-}$and $\mathrm{H}_{2} \mathrm{O}_{2}$ illustrated in Fig. 6 represent concentration changes of these species in snow over the last 6 months of 2008, based on local mean annual snow accumulation rate of $0.20 \mathrm{~m}_{\text {weq }} \mathrm{yr}^{-1}$ (Banta et al., 2008) and an average snow density of 0.37. Total concentrations of $\mathrm{NO}_{3}^{-}$in the snow column dropped by about $19 \%$ between the first and last snow-pit samplings. $\mathrm{NO}_{3}^{-}$concentrations decrease by $94-188$ ppbw over the top $5 \mathrm{~cm}$ of snow, reaching $\sim 30$ ppbw below. Total $\mathrm{NO}_{2}^{-}$ stored in the $30 \mathrm{~cm}$ column decreased by about $65 \%$ across the three snow-pit samplings. Unlike $\mathrm{NO}_{2}^{-}$and $\mathrm{NO}_{3}^{-}$, total 


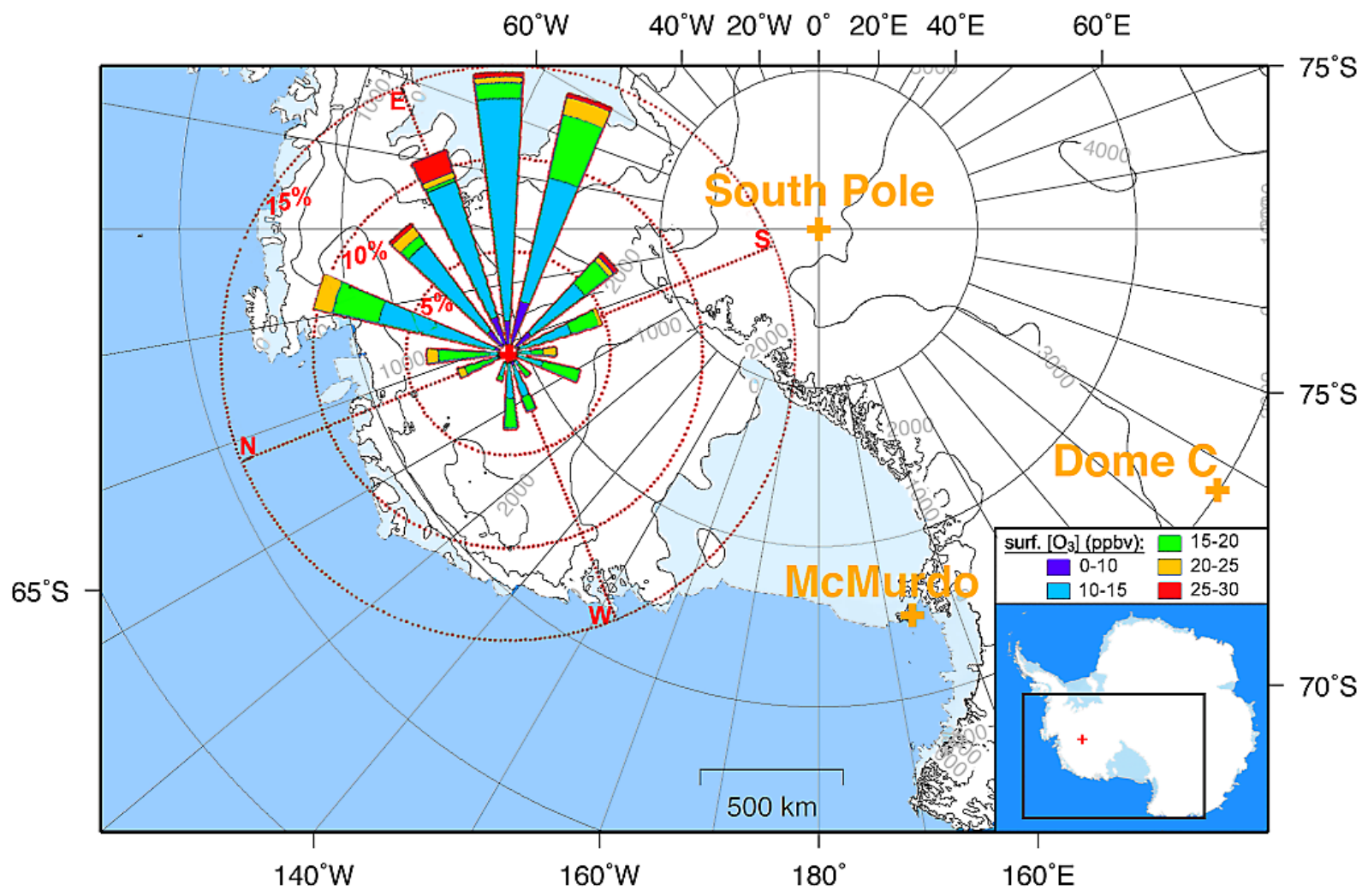

Fig. 4. The windrose for WAIS Divide for period of 10 December 2008 to 5 January 2009 and $\mathrm{O}_{3}$ concentrations from each direction for the same period.

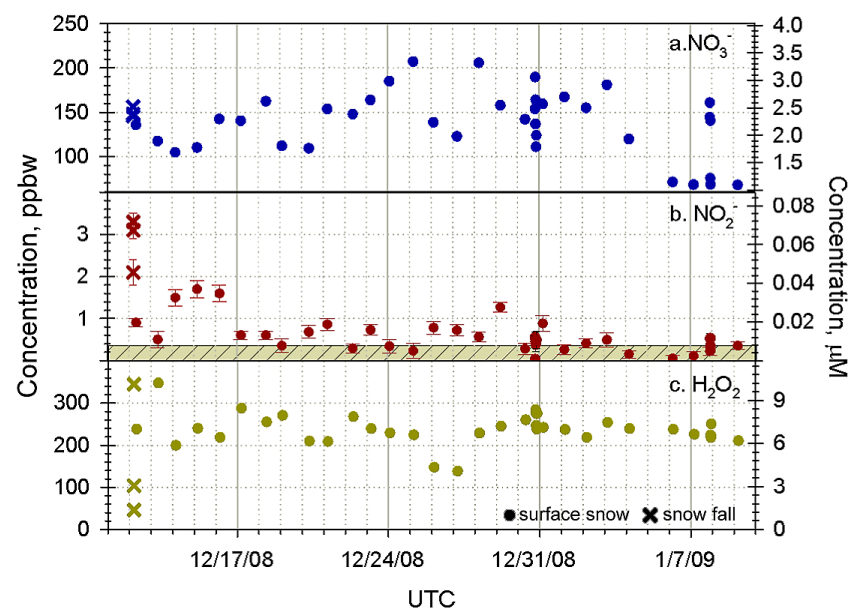

Fig. 5. Surface-snow concentrations and snow concentrations from the 12 December 2008 precipitation of (a) $\mathrm{NO}_{3}^{-}$, (b) $\mathrm{NO}_{2}^{-}$, (c) $\mathrm{H}_{2} \mathrm{O}_{2}$. The shaded area in (b) represents the $\mathrm{NO}_{2}^{-}$LOD.

concentrations of $\mathrm{H}_{2} \mathrm{O}_{2}$ in the top $30 \mathrm{~cm}$ of snowpack doubled over the 18 days of sampling. A 233-298 ppbw decrease of $\mathrm{H}_{2} \mathrm{O}_{2}$ concentrations in the first $10 \mathrm{~cm}$ of each snow pit was generally observed.

\section{Discussion}

\subsection{Local photochemistry}

\subsubsection{Factors controlling atmospheric levels of $\mathrm{ROOH}$, $\mathrm{NO}, \mathrm{O}_{3}$ and snow content of $\mathrm{NO}_{3}^{-}, \mathrm{NO}_{2}^{-}$and $\mathrm{H}_{2} \mathrm{O}_{2}$}

Levels of $\mathrm{NO}$ and $\mathrm{O}_{3}$ measured at WAIS Divide during summer 2008-2009 are slightly higher than coastal values but lower than observed concentrations on the Antarctic Plateau (Fig. 3). The observed mean of NO mixing rates are close to the 10 pptv modeled by Frey et al. (2005) at Byrd, about $160 \mathrm{~km}$ from WAIS Divide. Their potential NO concentrations were computed with the NASA Goddard Flight Center (GSFC) point photochemical model that included a snowpack source of $\mathrm{H}_{2} \mathrm{O}_{2}$ and $\mathrm{CH}_{2} \mathrm{O}$.

The diel cycle of $\mathrm{NO}$ (Fig. 2b) does not compare well with either measurements from the East Antarctic Plateau (Dome C) (Frey et al., 2013) or from the West Antarctic coast (Halley) (Bauguitte et al., 2012). Data show a symmetry of the NO diel cycle with respect to local noon that is similar to predictions and observations from Summit/Greenland (Thomas et al., 2012), but with lower mixing ratios and a diel amplitude of 6.5 pptv. The NO variability is mainly in phase with solar radiations but presents two minima around local 


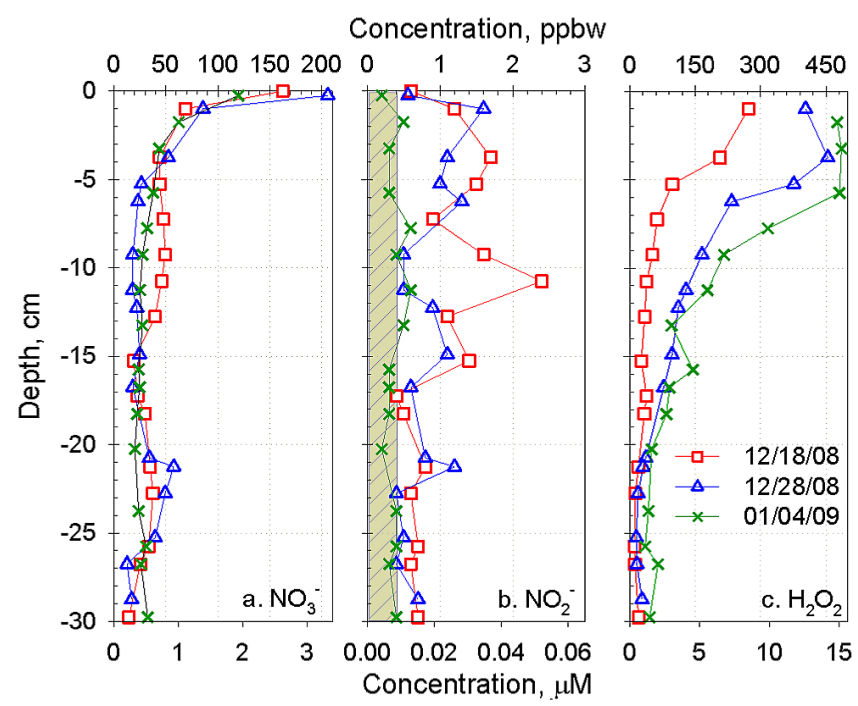

Fig. 6. Snow concentrations of (a) $\mathrm{NO}_{3}^{-}$, (b) $\mathrm{NO}_{2}^{-}$and (c) $\mathrm{H}_{2} \mathrm{O}_{2}$ measured in the $30 \mathrm{~cm}$-depth snow pits dug on 18 December 2008 (red squares), 28 December 2008 (blue triangles) and 04 January 2009 (green crosses). The shaded area in (b) represents the $\mathrm{NO}_{2}^{-}$LOD.

noon and midnight and two daily maxima around 07:00 and 19:00 LT. The $36 \%$ rise from the NO median of 10 pptv observed in the morning along with the increase of solar elevation angle suggests that the increase of solar elevation angle enhances the photolytic production of NO from the snowpack. The $2 \mathrm{~h}$ binned data of $\mathrm{NO}$ and wind speed (data not shown) suggest that higher NO mixing ratios were observed for wind speeds less than $3 \mathrm{~m} \mathrm{~s}^{-1}$, indicating a potential local production of NO from surface snow. The decrease observed after 09:00 LT at high solar elevation angle may result from the increase of the atmospheric boundary layer height and of the wind speed. Higher wind speeds would result in an increase of turbulent mixing and therefore in efficient vertical upward transport and dilution of surface emissions into a growing volume given by the developing boundary layer (Frey et al., 2013). The increase of NO levels by $20 \%$ of the median value around 19:00 LT may result from the decrease of the atmospheric boundary layer height and wind speed along with solar elevation angle. However, no measurements of the diel variability of the atmospheric boundary layer height were performed during the campaign to confirm this point. These data suggest that both snow photochemistry and physical mixing control the diel cycle of NO at WAIS Divide. Through its different sinks and sources, the $\mathrm{NO}_{\mathrm{x}}$ photochemistry may also drive the NO variability but this contribution cannot be defined here as it requires a more detailed analysis using a 1-D model (Thomas et al., 2012).

The interpretation of the 1 month record of $\mathrm{O}_{3}$ in terms of seasonal trend is made difficult given the short period of measurement. However, its comparison with the annual cycles of
$\mathrm{O}_{3}$ observed at other Antarctic stations, with concentrations between those observed at Halley and South Pole, suggests a possible influence of both marine and continental air on the WAIS Divide level, and shows characteristic low mixing ratios around the Austral solstice.

The $\mathrm{O}_{3}$ diel cycle (Fig. 2b) is similar to observations from Dome C (Legrand et al., 2009) but with lower amplitude and concentrations. The increase of $5 \%$ of the median value is consistent with $\mathrm{O}_{3}$ produced locally from the snowpack $\mathrm{NO}_{\mathrm{x}}$ emissions and confined into a shallow atmospheric boundary layer. Similarly to the NO diel cycle, the following decrease of $\mathrm{O}_{3}$ in the afternoon can be attributed to a deeper atmospheric boundary layer and higher wind speeds that dilute all the produced $\mathrm{O}_{3}$. Because the chemical lifetime of $\mathrm{O}_{3}$ in polar regions is in the order of days (Grannas et al., 2007), it is not expected that photochemical loss is a main driver of the diel cycle of $\mathrm{O}_{3}$. Lack of higher mixing ratios during periods with wind speed less than $3 \mathrm{~m} \mathrm{~s}^{-1}$ (data not shown) suggests that local production of $\mathrm{O}_{3}$ over the surface snow is not the predominant process at WAIS Divide during the austral summer. The amplitude of the diel cycle is relatively low in comparison with the average daily $\mathrm{O}_{3}$ which indicates that another source may be considered to explain the change of $\mathrm{O}_{3}$ over the campaign. The ENE to SWS wind directions associated with high $\mathrm{O}_{3}$ values (Fig. 4) point to a possible contribution of air mass transport of this chemical species at WAIS Divide, e.g. outflow from the East Antarctic Plateau (see Sect. 4.2). A similar conclusion was reached by Helmig et al. (2007a) from the review of other Antarctic station data.

$\mathrm{H}_{2} \mathrm{O}_{2}$ concentrations at WAIS Divide are similar to those observed above WAIS at lower latitudes (below $1500 \mathrm{~m}$ a.m.s.l.) but 3 times the mixing ratios measured at South Pole (Frey et al., 2009a). As shown in Table 1 and in Fig. 3, the concentrations of $\mathrm{H}_{2} \mathrm{O}_{2}$ measured at WAIS Divide are higher than those measured at nearby sites (Frey et al., 2005). A similar comparison between our average MHP mixing ratios and prior measurements across WAIS (Frey et al., 2005,2009 a) is also observed. The average specific humidity of $1.1 \mathrm{~g} \mathrm{~kg}^{-1}$ calculated for the period of ROOH measurement is higher than previous records from nearby sites (Frey et al., 2005). This high value may explain the elevated mixing ratios of $\mathrm{H}_{2} \mathrm{O}_{2}$ and MHP measured at WAIS Divide, as water vapor is an important precursor for both species.

$\mathrm{H}_{2} \mathrm{O}_{2}$ and MHP exhibited a simultaneous increase with solar elevation angle between 03:00-13:00 LT, followed by a decrease (Fig. 2). The maximum amplitude of $\mathrm{H}_{2} \mathrm{O}_{2}$ is observed at 05:00LT, with a rise of $43 \%$ above the median value of $695 \mathrm{pptv}$. For MHP, mixing ratios rose to a maximum of $37 \%$ above the median (464 pptv) at 05:00 and 13:00 LT. These results also suggest that both $\mathrm{H}_{2} \mathrm{O}_{2}$ and MHP may be affected by photochemistry and an increase of the atmospheric boundary layer depth during the day. Unlike $\mathrm{NO}, \mathrm{ROOH}$ did not show an increase in the second part of the day but the levels remained low, consistent with an increased uptake by the snowpack when the temperature decreased in 
the evening (Hutterli, 2003, and references therein). The temperature record at the WAIS Divide camp was, however, too intermittent to further investigate the influence of temperature on atmospheric $\mathrm{H}_{2} \mathrm{O}_{2}$. A source from the snowpack is not considered significant for MHP since it has a solubility only $0.1 \%$ that of $\mathrm{H}_{2} \mathrm{O}_{2}$ (Lind and Kok, 1994) and because no MHP has been detected in snow and ice above the current LOD (Frey et al., 2005, 2009a). The change of MHP may depend on the photochemistry of its precursors such as $\mathrm{CH}_{4}$, NMHCs and water vapor, which may decrease with solar elevation angle. Higher $\mathrm{H}_{2} \mathrm{O}_{2}$ and MHP levels at low wind speeds (less than $4 \mathrm{~ms}^{-1}$ ) (data not shown) suggest that ROOH are produced locally, coherent with a local photochemical production of MHP and a physical snow-air exchange controlling $\mathrm{H}_{2} \mathrm{O}_{2}$ (Frey et al., 2009a). They are then diluted through turbulent transport after production.

$\mathrm{NO}_{3}^{-}$values are closer to those measured at coastal sites such as Halley or Neumayer stations (Mulvaney et al., 1998), than to the values observed at higher-altitude sites such as South Pole and Concordia stations (Dibb et al., 2004; France et al., 2011). Concentrations of skin-layer $\mathrm{NO}_{3}^{-}$present short-term and local spatial variations as Jarvis et al. (2009) and Wolff et al. (2008) also observed at Summit and Halley. These variations cannot be explained with a scenario of fresh snowfall since only one snow precipitation occurred during the campaign (Fig. 5). Part of these variations of $\mathrm{NO}_{3}^{-}$in the skin layer as $\mathrm{H}_{2} \mathrm{O}_{2}$ may be caused by processes such as nighttime deposition of $\mathrm{NO}_{3}^{-}$, in the form of nitric oxide $\left(\mathrm{HNO}_{3}\right)$ and $\mathrm{H}_{2} \mathrm{O}_{2}$ or $\mathrm{HNO}_{3}$ and $\mathrm{H}_{2} \mathrm{O}_{2}$ gas exchange. Other part can be attributed to some events of snow removed by the wind since this snow removal would also impact on chemical species other than $\mathrm{NO}_{3}^{-}$(such as $\mathrm{H}_{2} \mathrm{O}_{2}$, which presents similar variations to $\mathrm{NO}_{3}^{-}$) on 26-27 December 2008 and on 1-2 January 2009. However, these events are too episodic to explain the overall variations of skin-layer $\mathrm{NO}_{3}^{-}$. It is suggested that part of $\mathrm{NO}_{3}^{-}$in the top snowpack undergoes some possible post-depositional processes such as photolysis.

The contents of $\mathrm{NO}_{3}^{-}$and $\mathrm{H}_{2} \mathrm{O}_{2}$ in fresh snowfall are in the range of skin-layer concentrations, while previous observations showed that fresh snowfall contains higher concentrations of these species than does aged snow (e.g., Mulvaney et al., 1998). In addition to post-depositional equilibrium with the atmosphere, it is possible that either the snow may have degassed during its collection or prior to analysis. Anastasio and Robles (2007) showed that $\mathrm{NO}_{3}^{-}$and $\mathrm{H}_{2} \mathrm{O}_{2}$ contribute to half the light absorption in polar snow for wavelengths of $280 \mathrm{~nm}$ and above. Since the snowflakes from this diamond-dust-like precipitation stayed exposed to the sun under a clear sky until their collection at the end of the event - over $5 \mathrm{~h}$ - it is possible that photochemical loss of $\mathrm{NO}_{3}^{-}$ and $\mathrm{H}_{2} \mathrm{O}_{2}$ may have occurred during the collection process.

The $\mathrm{NO}_{3}^{-}$and $\mathrm{H}_{2} \mathrm{O}_{2}$ profiles measured in the $30 \mathrm{~cm}$ snow pits show a summer peak, as observed in earlier studies (Kreutz et al., 1999, and references therein). The increase over the campaign of $\mathrm{H}_{2} \mathrm{O}_{2}$ concentrations in the top $15 \mathrm{~cm}$ of snow (Fig. 6) may point to a significant deposition of $\mathrm{H}_{2} \mathrm{O}_{2}$ during summer, and may also reflect changes in the overlying atmospheric $\mathrm{H}_{2} \mathrm{O}_{2}$ levels, as discussed in Hutterli (2003). $\mathrm{NO}_{3}^{-}$in the skin layer does not show a constant increase with time, unlike $\mathrm{H}_{2} \mathrm{O}_{2}$. However, a $70 \%$ decrease of $\mathrm{NO}_{3}^{-}$concentrations with increasing depth in the snow is observed, unlike reported snow-pit measurements from polar sites with similar surface temperature and snow accumulation rate, such as Summit, Greenland (e.g., Burkhart et al., 2004). These $\mathrm{NO}_{3}^{-}$profiles are similar to those observed at Dome C (e.g., Frey et al., 2009b; France et al., 2011). Based on the interpretation of these authors, this sharp decrease may therefore indicate that $\mathrm{NO}_{3}^{-}$in the top snowpack can be significantly reduced by photolysis. A similar photochemical depletion can be suggested to explain the slight decrease of $\mathrm{NO}_{2}^{-}$concentration observed in the $30 \mathrm{~cm}$ deep profiles over the campaign.

\subsubsection{Post-depositional loss of $\mathrm{NO}_{3}^{-}$in surface snowpack}

WAIS Divide and Summit, Greenland, have similar latitudes, surface temperature and snow accumulation rate (Table 2 and Fig. 7a). Concentrations of $\mathrm{NO}_{3}^{-}$in the skin layer are also in the same range for both sites, between 24206 ppbw for WAIS Divide and 61-207 ppbw for Summit (Fig. 8a, b).

However, the median $\mathrm{NO}_{3}^{-}$concentrations in the top $1 \mathrm{~m}$ of snow at WAIS Divide is lower than at Summit, 38 vs. 138 ppbw. At very dry and cold sites on the East Antarctic Plateau such as Dome $\mathrm{C}$, mean $\mathrm{NO}_{3}^{-}$concentrations are as low as 10-20 ppbw if one excludes the surface layer (Fig. 8c). Note that at Dome $\mathrm{C}$ most $\mathrm{NO}_{3}^{-}$is concentrated in the top layer with levels 1-2 orders of magnitude larger than at depth (Frey et al., 2009b; Erbland et al., 2013). Comparison of concentrations at the surface and at depth allows estimating net preservation of $\mathrm{NO}_{3}^{-}$in snow, which is about $30 \%$ at WAIS Divide, 75-93\% at Summit (Burkhart et al., 2004; Dibb et al., 2007) and less than $10 \%$ at Dome C (Rothlisberger et al., 2002; Frey et al., 2009b).

Differences in average $\mathrm{NO}_{3}^{-}$concentrations in the skin layer and preserved at depth between WAIS Divide and Summit can be attributed to (a) a lower background of atmospheric reactive nitrogen in Antarctica compared to the Arctic due to a larger distance from anthropogenic pollution sources, and (b) differences in processes occurring during and after deposition.

Regarding (b), the relative contributions of the processes involved may vary significantly between different locations, i.e., both physical (evaporation and adsorption of $\mathrm{HNO}_{3}$ ) and photochemical (photolysis of $\mathrm{NO}_{3}^{-}$) processes have been put forward to explain $\mathrm{NO}_{3}^{-}$net preservation (sum of gain and loss) in polar snow (Rothlisberger et al., 2002; Frey et al., 2009 b). Both processes will be sensitive to accumulation rate and timing. For example, little snowfall in the sunlit season 
Table 2. Concentrations of major ions (in ppbw) measured in surface snow at WAIS Divide and Summit, Greenland, and the respective estimated $\mathrm{pH}$ and alkalinity.

\begin{tabular}{|c|c|c|c|c|c|c|c|c|c|c|}
\hline $\begin{array}{l}\text { Sampling } \\
\text { year }\end{array}$ & $\mathrm{Na}^{+}$ & $\mathrm{NH}_{4}^{+}$ & $\mathrm{K}^{+}$ & $\mathrm{Mg}^{2+}$ & $\mathrm{Ca}^{2+}$ & $\mathrm{Cl}^{-}$ & $\mathrm{NO}_{3}^{-}$ & $\mathrm{SO}_{4}^{2-}$ & $\mathrm{pH}^{\mathrm{a}}$ & Alk. ${ }^{b}$ \\
\hline \multicolumn{11}{|c|}{ WAIS Divide $\left(T_{\text {air }}=-28.5^{\circ} \mathrm{C} ;\right.$ Acc $\left.=20 \mathrm{~cm}_{\text {weq }} \mathrm{yr}^{-1}\right)$} \\
\hline $2000^{\mathrm{c}}$ & 13 & - & 16 & 1 & 8 & 24 & 24 & 24 & 6.1 & 0.37 \\
\hline $2006^{\mathrm{d}}$ & 6 & 4 & 2 & 1 & 1 & 33 & 61 & 43 & 5.6 & 0.34 \\
\hline $2006^{\mathrm{g}}$ & 4 & 2 & 0.4 & 1 & 2 & 31 & 62 & 42 & 5.6 & 0.27 \\
\hline \multirow[t]{2}{*}{$2008^{\mathrm{e}}$} & 31 & - & 2 & 5 & 5 & 54 & 67 & 41 & 5.8 & 0.29 \\
\hline & & & & & & & & Average & 5.8 & 0.32 \\
\hline \multicolumn{11}{|c|}{ Summit $\left(T_{\text {air }}=-29.5^{\circ} \mathrm{C} ;\right.$ Acc $\left.=24 \mathrm{~cm}_{\text {weq }} \mathrm{yr}^{-1}\right)$} \\
\hline $1987^{\mathrm{f}}$ & 2 & 6 & 1 & 1 & 15 & 8 & 40 & 40 & 5.6 & 1.2 \\
\hline $2003-2009 \mathrm{~g}$ & 8 & 21 & 10 & 2 & 18 & 42 & 234 & 107 & 5.2 & 2.4 \\
\hline $2007^{\mathrm{h}}$ & 4 & 10 & 3 & 2 & 19 & 23 & 195 & 72 & 5.3 & 1.6 \\
\hline \multirow[t]{2}{*}{$2008^{\mathrm{e}}$} & 3 & 5 & 3 & 1 & 6 & 19 & 239 & 54 & 5.3 & 0.65 \\
\hline & & & & & & & & Average & 5.3 & 1.5 \\
\hline
\end{tabular}

a Based on $\left[\mathrm{H}^{+}\right]=\left(\left[\mathrm{SO}_{4}^{2-}\right]-0.12 \times\left[\mathrm{Na}^{+}\right]\right)+\left[\mathrm{NO}_{3}^{+}\right]+\left(\left[\mathrm{Cl}^{-}\right]-1.17 \times\left[\mathrm{Na}^{+}\right]\right)($Legrand and Delmas, 1988).

${ }^{\mathrm{b}} \mathrm{In} \mu \mathrm{eq} \mathrm{L}^{-1}$, derived from the ionic balance and attributing the missing part of anions to dissolved carbonate.

${ }^{c}$ Site ITASE 00-1, top $2 \mathrm{~cm}$ of surface snow; unpublished data (Mayewski and Dixon, 2005).

d Top $3 \mathrm{~cm}$ of surface snow with the first $\mathrm{cm}$ removed, unpublished data from http://www.waisdivide.unh.edu.

e Top $3 \mathrm{~cm}$ of surface snow, unpublished data (Kreutz and Koffman, 2011).

${ }^{\mathrm{f}}$ Top $3 \mathrm{~cm}$ of surface snow (Mayewski et al., 1990).

$\mathrm{g}$ Top $1 \mathrm{~cm}$ of surface snow, unpublished data from http://niflheim.nilu.no/geosummit/.

h Top $0.5 \mathrm{~cm}$ of surface snow (range $0.1-6 \mathrm{~cm}$, Dibb et al., 2010).

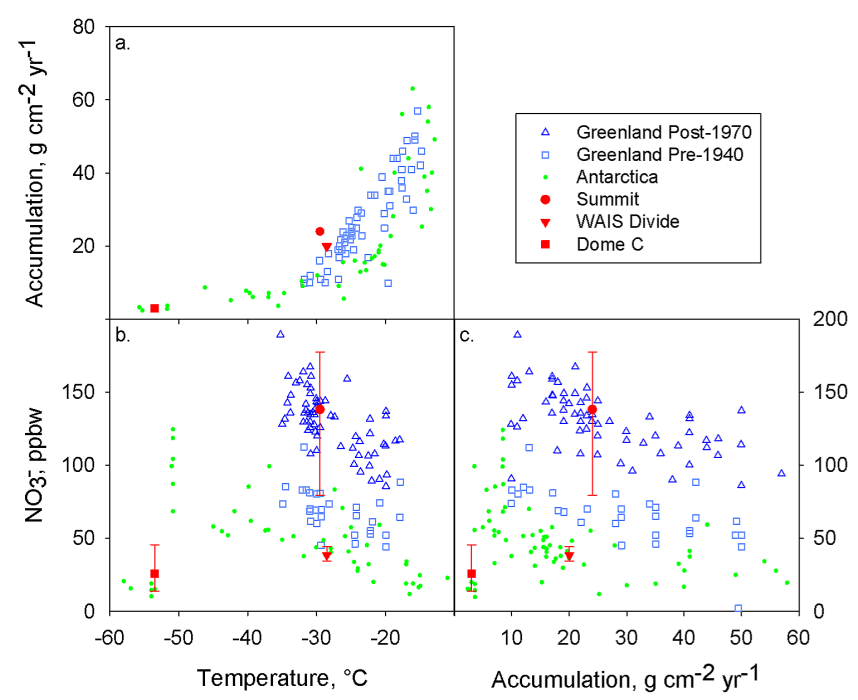

Fig. 7. Updated Figs. 2, 3 and 4 from Rothlisberger et al. (2002) with additional measurements from WAIS Divide, Summit, and Dome C (median and range). Data reported from Greenland are $\mathrm{NO}_{3}^{-}$concentrations in snow deposited either before 1940 (squares) or after 1970 (triangles). The $\mathrm{NO}_{3}^{-}$levels observed in the snow deposited after 1970 over Greenland are influenced by anthropogenic emissions that do not reach the Antarctic continent, whereas the difference between the pre-1940s records and the Antarctic data is likely due to a difference in alkalinity. implies longer exposure of surface snow to UV radiation, leading to significant loss of $\mathrm{NO}_{3}^{-}$at some sites from photolysis (Frey et al., 2009b; Erbland et al., 2013).

In general, $\mathrm{NO}_{3}^{-}$concentration preserved in polar snow scale with mean annual temperature and accumulation rate (Rothlisberger et al., 2002, Fig. 7). Comparison shows that $\mathrm{NO}_{3}^{-}$concentrations at WAIS Divide are not unusual at all since they do fall into the range expected in Antarctica (Fig. 7b, c). They are, however, still lower than those in pre1940 snow at Greenlandic sites of similar accumulation rate and temperature. The slightly lower accumulation and thus slower burial rate of annual snow deposition at WAIS Divide vs. Summit may contribute to this difference in $\mathrm{NO}_{3}^{-}$preservation.

But, as suggested by the recent literature, variables linked to (post)depositional processes other than accumulation rate may contribute as well to the observed difference and include micro-physical properties and chemical heterogeneity in the snow matrix. Regarding the latter, observations of atmospheric and snow $\mathrm{NO}_{3}^{-}$in coastal Antarctica showed that deposition of $\mathrm{NO}_{3}^{-}$spikes is linked to sea salt aerosol, i.e., by conversion of gas-phase $\mathrm{NO}_{3}^{-}$to $\mathrm{NO}_{3}^{-}$aerosol and enhanced trapping of gas-phase $\mathrm{NO}_{3}^{-}$on salty surfaces (Wolff et al., 2008). This enhanced deposition efficiency will be less important further inland. However, higher $\mathrm{NO}_{3}^{-}$concentrations were also associated with higher dust content (i.e., calcium $\left(\mathrm{Ca}^{2+}\right)$ ), suggesting reduced post-depositional loss of $\mathrm{NO}_{3}^{-}$ by photolysis or evaporation (Rothlisberger et al., 2000). In 


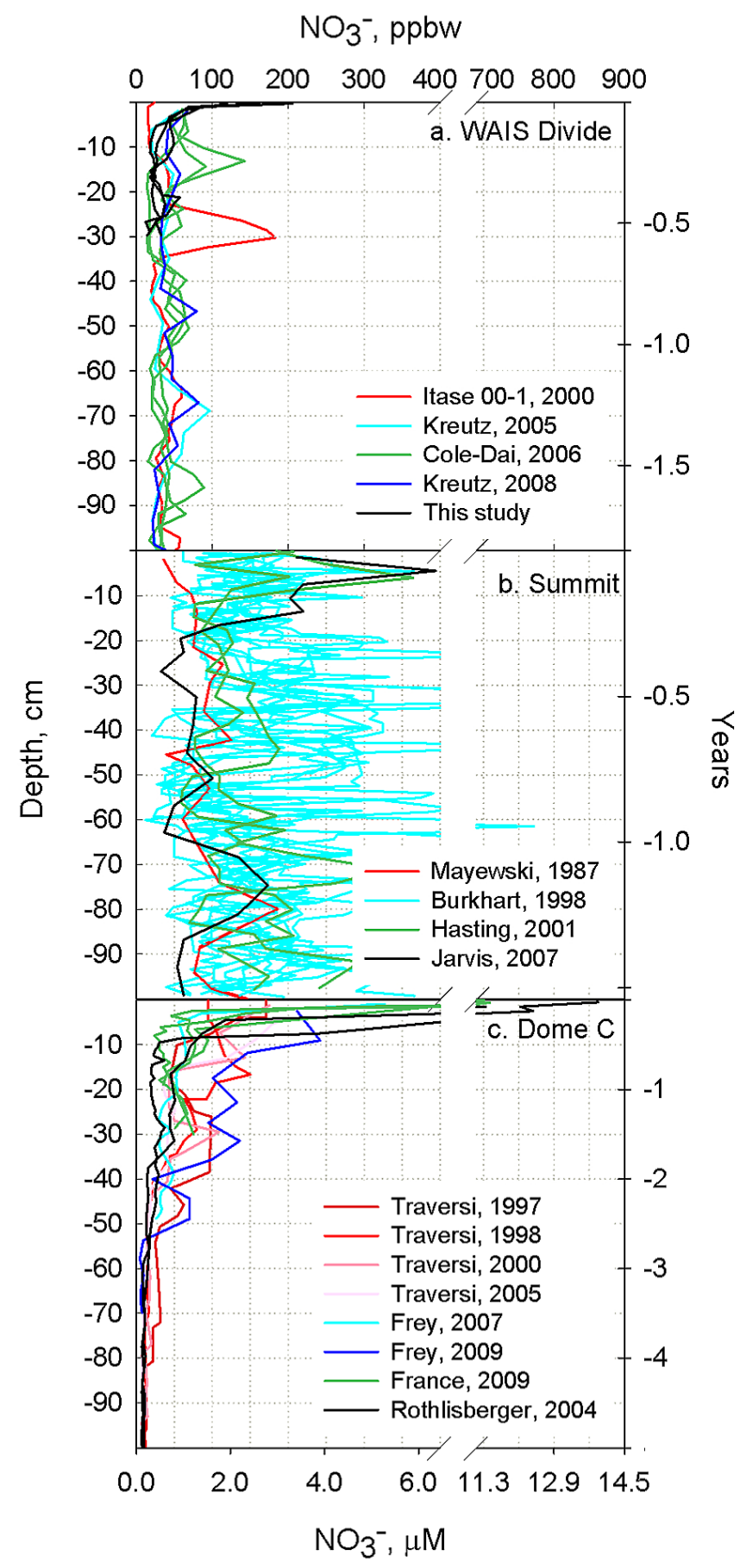

Fig. 8. The $1 \mathrm{~m} \mathrm{NO}_{3}^{-}$profiles from snowpits reported from WAIS Divide, Summit, and Dome C (Frey et al., 2013; France et al., 2011; Traversi et al., 2009; Burkhart et al., 2004; Hastings, 2004; Rothlisberger et al., 2000; Mayewski et al., 1990, Jarvis (unpublished data)).

comparison with Summit, the lower dust content in WAIS Divide snow, $\sim 20 \%$ as alkaline and $\sim 30 \%$ as much $\mathrm{Ca}^{2+}$ (Table 2), may reduce the preservation of $\mathrm{NO}_{3}^{-}$in snow and enhance the $\mathrm{NO}_{\mathrm{x}}$ emission flux in summer. Systematic dif- ferences of $\mathrm{NO}_{\mathrm{x}}$ emissions from surface snow could indeed further support increased loss rates and thus less preservation of $\mathrm{NO}_{3}^{-}$in surface snow at WAIS Divide. At Summit, Honrath et al. (2002) measured $24 \mathrm{~h}$ average $\mathrm{NO}_{\mathrm{x}}$ fluxes of $2.5 \times 10^{8}$ molecule $\mathrm{cm}^{-2} \mathrm{~s}^{-1}$, significantly less than what we calculated for WAIS Divide (see Sec. 4.1.5). However, based on a similar approach to our study, Zatko et al. (2013) recently modeled an $\mathrm{NO}_{\mathrm{x}}$ flux at Summit 5-10 times that reported by Honrath et al. (2002). These results point to significant $\mathrm{NO}_{\mathrm{x}}$ emissions from $\mathrm{NO}_{3}^{-}$in the snowpack at both sites. Our calculations suggest high loss rates, higher than at Summit (see Sect. 4.1.5), but uncertainties in available measurements and model estimates prevent concluding that emission rates are significantly higher at WAIS Divide than at Summit.

Further, the stable isotopic composition of $\mathrm{NO}_{3}^{-}$in snow can provide information on the amount of post-depositional $\mathrm{NO}_{3}^{-}$loss (e.g., Frey et al., 2009b; Erbland et al., 2013). At Summit, the $\mathrm{N}$ and $\mathrm{O}$ isotopes of $\mathrm{NO}_{3}^{-}$showed that most of the $\mathrm{NO}_{\mathrm{x}}$ emitted from the surface snow is recycled back to the snow as $\mathrm{NO}_{3}^{-}$, explaining high $\mathrm{NO}_{3}^{-}$preservation (Hastings, 2004). It can be speculated that if the $\mathrm{NO}_{3}^{-}$ loss rate was similar at WAIS Divide, then some of the emitted gas phase species may be lost through lateral export, implying a lower recycling efficiency and therefore lower $\mathrm{NO}_{3}^{-}$preservation. Thus, $\mathrm{NO}_{3}^{-}$post-depositional loss is a nonlinear combination of both accumulation and temperature, but other parameters need also to be considered including snow chemistry to get a more complete process understanding.

\subsubsection{Steady-state estimation of atmospheric $\mathrm{NO}_{2}$}

Considering the $\mathrm{NO}-\mathrm{NO}_{2}-\mathrm{O}_{3}$ system, it is reasonable to assume a photo-stationary steady state between $\mathrm{NO}$ and $\mathrm{NO}_{2}$ at $1 \mathrm{~m}$ above the snowpack (Frey et al., 2013) to infer the potential atmospheric $\mathrm{NO}_{2}$ concentrations from reactions:

$$
\begin{aligned}
& \left.\mathrm{NO}_{2}+\mathrm{h} v \rightarrow \mathrm{NO}+\mathrm{O}^{3} \mathrm{P}\right) \\
& \mathrm{O}\left({ }^{3} \mathrm{P}\right)+\mathrm{O}_{2}+\mathrm{M} \rightarrow \mathrm{O}_{3}+\mathrm{M} \\
& \mathrm{NO}+\mathrm{O}_{3} \rightarrow \mathrm{NO}_{2}+\mathrm{O}_{2}
\end{aligned}
$$

The conversion of $\mathrm{NO}$ to $\mathrm{NO}_{2}$ described in Reaction (R4) is also achieved through different channels (Reactions R1, R5-R6) with the presence of oxidants such as $\mathrm{HO}_{\mathrm{x}}$, peroxy $\left(\mathrm{RO}_{2}\right)$ or halogen $(\mathrm{XO}=\mathrm{ClO}, \mathrm{BrO}, \mathrm{IO})$ radicals:

$\mathrm{NO}+\mathrm{RO}_{2} \rightarrow \mathrm{NO}_{2}+\mathrm{RO}$

$\mathrm{NO}+\mathrm{XO} \rightarrow \mathrm{NO}_{2}+\mathrm{X}$

$\mathrm{NO}_{2}$ mixing ratios can therefore be estimated from the extended Leighton ratio as derived in Ridley et al. (2000):

$\left[\mathrm{NO}_{2}\right]=[\mathrm{NO}] \frac{k_{\mathrm{R} 4}\left[\mathrm{O}_{3}\right]+k_{\mathrm{R} 1}[\mathrm{OX}]}{j_{\mathrm{R} 2}}$ 
with $\mathrm{OX}$ the total radical concentration $\left([\mathrm{OX}]=\left[\mathrm{HO}_{2}\right]+\left[\mathrm{RO}_{2}\right]+2[\mathrm{XO}]\right)$ as $\mathrm{XO}$ represents the halogen radicals (Ridley et al., 2000). The photolytic rate constant $j_{\mathrm{R} 2}$ was calculated from the NCAR/ACD radiative-transfer model TUV version 5.0 (Lee-Taylor and Madronich, 2002) with $\mathrm{O}_{3}$ columns measured by total ozone mapping spectrometer (TOMS) (http: //ozoneaq.gsfc.nasa.gov/ozone_overhead_current_v8.md) and assuming clear-sky conditions. $k_{\mathrm{R} 4}$ and $k_{\mathrm{R} 1}$ were estimated through the temperature-dependent expressions from Sander et al. (2006). An $\mathrm{NO}_{2}$ concentration of 5 pptv was computed based on the averages of $\mathrm{NO}$ and $\mathrm{O}_{3}$ observed at WAIS Divide, and on $4.9 \times 10^{7}$ molecule $\mathrm{cm}^{-3} \mathrm{HO}_{2}+\mathrm{RO}_{2}$ mixing ratios derived from the $1.3 \times 10^{6}$ molecule $\mathrm{cm}^{-3}$ $\mathrm{OH}$ radical concentrations computed for Byrd (Frey et al., 2005). Because the mixing ratios of $\mathrm{HO}_{\mathrm{x}}$ for WAIS Divide are estimates, we calculated the steady-state $\mathrm{NO}_{2}$ concentrations with reported $\mathrm{HO}_{\mathrm{x}}$ levels from Halley $\left(2.3 \times 10^{7}\right.$ molecule $\left.\mathrm{cm}^{-3}\right)$ (Bloss et al., 2007) and South

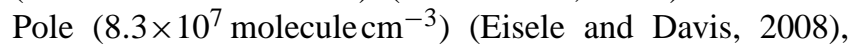
resulting in $\mathrm{NO}_{2}$ concentrations of 5.1 and $6.1 \mathrm{pptv}$, respectively. These results show that this steady state relationship depends essentially on $\mathrm{NO}$ and $\mathrm{O}_{3}$ mixing ratios.

Note that halogen radicals were not considered in these calculations, and no records have yet been reported above WAIS. Coastal sea ice is the main source of active halogen (Saiz-Lopez and von Glasow, 2012, and references therein) and measurements from Antarctic coastal sites showed a strong spatial variability in concentrations of halogens and their potential impact on boundary layer photochemistry. Summertime measurements of $\mathrm{IO}$ and $\mathrm{BrO}$ ranged from 0.7 to $5.5 \mathrm{pptv}$ at Halley (Saiz-Lopez et al., 2007), while mixing ratios at Dumont D'Urville were observed between 0.04 and $0.15 \mathrm{pptv}$ for IO and below or equal to $2 \mathrm{pptv}$ for $\mathrm{BrO}$ (Grilli et al., 2013). The back-trajectory analysis described in Sect. 4.2.1 shows that marine intrusions over WAIS are frequent (58\% of all back trajectories) and have therefore the potential to export halogen compounds over the ice sheet. However, from measurements by the satellite spectrometer SCIAMACHY (Schönhardt et al., 2012), monthly mean IO and $\mathrm{BrO}$ vertical column amounts averaged over 2004 to 2009 revealed insignificant concentrations of both species over WAIS Divide between December and January. Thus, it is reasonable to assume that little or insignificant halogen chemistry is occurring at WAIS Divide.

The NO: $\mathrm{NO}_{2}$ ratio of 3.8 is significantly higher than the ratios of 1.3-2 and 1.5 observed respectively at Halley (Bauguitte et al., 2012, and references therein) and Dome C (Frey et al., 2013). These studies showed evidence of large discrepancies between observed and steady-state estimated ratios that are attributed to halogen chemistry for the coastal station and to the presence of $\mathrm{HO}_{2}+\mathrm{RO}_{2}$ on the plateau. Therefore, the estimated atmospheric $\mathrm{NO}_{2}$ from the steadystate assumption has to be considered as a lower limit of true value.

\subsubsection{Potential $\mathrm{NO}_{\mathrm{x}}$ lifetime}

The $\mathrm{NO}_{\mathrm{x}}$ lifetime was calculated to investigate the factors controlling its atmospheric concentration. Assuming that halogen chemistry is not significant at WAIS Divide, Reactions (R7)-(R8) are the main sink of $\mathrm{NO}_{2}$ during polar day:

$\mathrm{NO}_{2}+\mathrm{OH}+\mathrm{M} \rightarrow \mathrm{HNO}_{3}+\mathrm{M}$

$\mathrm{NO}_{2}+\mathrm{HO}_{2}+\mathrm{M} \rightarrow \mathrm{HNO}_{4}+\mathrm{M}$

Based on these reactions, the lifetime of $\mathrm{NO}_{2}\left(\tau_{\mathrm{NO}_{2}}\right)$ was estimated with $[\mathrm{OH}]=1.3 \times 10^{6}$ molecule $\mathrm{cm}^{-3}$ and $\left[\mathrm{HO}_{2}\right]=4.9 \times 10^{7}$ molecule $\mathrm{cm}^{-3}$ (Sect. 4.1.3). The lifetime of $\mathrm{NO}_{\mathrm{x}}\left(\tau_{\mathrm{NO}_{\mathrm{x}}}\right)$ was then deduced through Eq. (2) (Seinfeld and Pandis, 1998):

$\tau_{\mathrm{NO}_{\mathrm{x}}}=\tau_{\mathrm{NO}_{2}} \times\left(1+\frac{[\mathrm{NO}]}{\left[\mathrm{NO}_{2}\right]}\right)$.

The resulting lifetime of $\mathrm{NO}_{\mathrm{x}}$ at WAIS Divide of $15 \mathrm{~h}$ represents an upper bound, given that the $\mathrm{NO}: \mathrm{NO}_{2}$ ratio of 3.8 is an upper limit. This value is less than the $24 \mathrm{~h}$ estimated by Jones et al. (2000) from a snow block at Neumayer, but it is longer than the $6.4 \mathrm{~h}$ estimated at Halley (Bauguitte et al., 2012) and $8 \mathrm{~h}$ at South Pole (Davis et al., 2004). Bauguitte et al. (2012) showed that $\mathrm{NO}_{2}$ lifetime at Halley is mainly controlled by halogen oxidation processes, while low temperatures at South Pole prevent thermal decomposition of pernitric acid and therefore enhance $\mathrm{NO}_{2}$ removal through its oxidation with $\mathrm{HO}_{2}$ (Slusher et al., 2002). Thus, our potential $\mathrm{NO}_{\mathrm{x}}$ lifetime seems plausible since we expect to observe none of these conditions at WAIS Divide. $\mathrm{NO}_{\mathrm{x}}$ lifetimes computed with reported $\mathrm{HO}_{\mathrm{x}}$ concentrations from South Pole and Halley (Sect. 4.1.3) are respectively 9 and $33 \mathrm{~h}$ and represent the potential lower and upper bounds for the $\mathrm{NO}_{\mathrm{x}}$ lifetime in the inner WAIS.

Considering a photochemical lifetime of other $\mathrm{NO}_{\mathrm{x}}$ precursors, such as $\mathrm{HNO}_{4}$ and $\mathrm{HNO}_{3}\left(\mathrm{HNO}_{3}\right.$ compared to dry deposition), of less than a day above the East Antarctic Plateau (Davis et al., 2008; Slusher et al., 2002) and an air mass transport between WAIS Divide and the Plateau longer than $33 \mathrm{~h}$ (Sect. 4.2), outflows from this region are not expected to be a major $\mathrm{NO}_{\mathrm{x}}$ source for the boundary layer at WAIS.

\subsubsection{Calculation of upper-limit $\mathrm{NO}_{\mathrm{x}}$ emission from $\mathrm{NO}_{3}^{-}$and $\mathrm{NO}_{2}^{-}$photolysis}

The simplified reaction scheme (R9) to (R12) summarizes the currently known $\mathrm{NO}_{3}^{-}$photochemistry in near-surface snow:

$\mathrm{NO}_{3}^{-}+\mathrm{h} v \rightarrow \mathrm{NO}_{2}+\mathrm{O}^{-}$ 
$\mathrm{NO}_{3}^{-}+\mathrm{h} v \rightarrow \mathrm{NO}_{2}^{-}+\mathrm{O}\left({ }^{3} \mathrm{P}\right)$

$\mathrm{NO}_{2}^{-}+\mathrm{h} v \rightarrow \mathrm{NO}+\mathrm{O}^{-}$

$\mathrm{NO}_{2}^{-}+\mathrm{OH} \rightarrow \mathrm{NO}_{2}+\mathrm{OH}^{-}$

While $\mathrm{NO}_{3}^{-}$photolysis is the major source of $\mathrm{NO}_{2}$ (Reaction R9) (Grannas et al., 2007), recent studies also pointed at the potential contribution of the photolysis of $\mathrm{NO}_{2}^{-}$to produce nitric oxide (Reaction R11) (France et al., 2012, and references therein). Therefore, calculations of the $\mathrm{NO}_{\mathrm{x}}$ emission flux in snow were based on Reactions (R9) and (R11) for the respective wavelengths $280-360 \mathrm{~nm}$ and $280-400 \mathrm{~nm}$ (Chu and Anastasio, 2003, 2007, and references therein). The first-order rate constants for the photolysis of $\mathrm{NO}_{3}^{-}$at the snowpack surface $j_{\mathrm{NO}_{3}^{-}, z 0}$ were calculated as defined in Seinfeld and Pandis (1998):

$j_{\mathrm{NO}_{3}^{-}, z_{0}}=\int_{\lambda i}^{\lambda j} \sigma_{\mathrm{NO}_{3}^{-}}(\lambda, T) \phi_{\mathrm{NO}_{3}^{-}}(\lambda, T) I\left(\lambda, \theta, z_{0}\right) \mathrm{d} \lambda$.

Based on the results of Chu and Anastasio (2003), the spectral UV absorptivity $\sigma_{\mathrm{NO}_{3}^{-}}(\lambda, T)$ was derived between 280 to $360 \mathrm{~nm}$ from the measured molar absorption coefficients of aqueous $\mathrm{NO}_{3}^{-}$at $278 \mathrm{~K}$ and a quantum yield $\phi_{\mathrm{NO}_{3}^{-}}$ $(\lambda, T)$ of $2.79 \times 10^{-3}$ was estimated for $T=259 \mathrm{~K}$, the average temperature over the three sampling days. The first-order rate constants for the photolysis of $\mathrm{NO}_{2}^{-}$at the snow surface $j_{\mathrm{NO}_{2}^{-}, z_{0}}$ were calculated with the same approach. $\sigma_{\mathrm{NO}_{2}^{-}}(\lambda, T)$ was calculated between 280 to $400 \mathrm{~nm}$ from reported molar absorptivities for aqueous $\mathrm{NO}_{2}^{-}$at $274 \mathrm{~K}$ and a range of $\phi_{\mathrm{NO}_{2}^{-}}(\lambda, T)$ of $3.4 \times 10^{-2}-0.9 \times 10^{-2}$ for $\lambda$ between 280 and $400 \mathrm{~nm}$ was also determined for $T=259 \mathrm{~K}$ (Chu and Anastasio, 2007). The actinic fluxes $\mathrm{I}\left(\lambda, \theta, z_{0}\right)$ were computed with the NCAR/ACD radiative transfer model TUV version 5.0 under clear-sky conditions for a $23^{\circ}$ solar elevation angle ( $\mathrm{SEA}=90^{\circ}-\theta$, with $\theta$ the solar zenith angle) averaged over the three sampling days.

The transmission of light in snow that drives the photochemistry in the top snowpack is controlled by optical processes: scattering and absorption (Dominé et al., 2008; Grannas et al., 2007, and references therein). These processes are summarized in the parameter $e$-folding depth (EFD), which in turn depends on snow physical properties - grain size, density, liquid water content - and the concentration of light-absorbing impurities such as black carbon. Studies at Dome C (France et al., 2011) and Barrow, Alaska (Reay et al., 2012), showed that absorption in snow layers, and therefore EFD, is inversely proportional to the content of black carbon in snow. Reported concentrations of black carbon in snow at WAIS Divide of $0.08 \pm 0.4 \mathrm{ng} \mathrm{g}^{-1}$ (average $\pm 1 \sigma)$ are in the range of those measured at South Pole, $0.2-$ $0.3 \mathrm{ng} \mathrm{g}^{-1}$ (Bisiaux et al., 2012, and references therein). Values of $j_{\mathrm{NO}_{3}^{-}, z_{0}}$ and $j_{\mathrm{NO}_{2}^{-}, z_{0}}$ were then scaled as a function of depth $(z)$ using an EFD of $30 \mathrm{~cm}$ (Table 3), based on the similar value calculated for South Pole by Zatko et al. (2013):

$j_{\mathrm{NO}_{3}^{-}}=j_{\mathrm{NO}_{3}^{-}, z_{0}} \times \exp \left(\frac{-z}{\mathrm{EFD}}\right)$.

The depth-integrated emission flux of $\mathrm{NO}_{\mathrm{x}}$ was calculated for 18 and 28 December 2008 and 4 January 2009 with

$\begin{aligned} F_{\mathrm{NO}_{2}} & =\int_{z=0 \mathrm{~cm}}^{z=30 \mathrm{~cm}}\left[\mathrm{NO}_{3}^{-}\right]_{z} j_{\mathrm{NO}_{3}^{-}, z} \mathrm{~d} z \\ F_{\mathrm{NO}} & =\int_{z=0 \mathrm{~cm}}^{z=30 \mathrm{~cm}}\left[\mathrm{NO}_{2}^{-}\right]_{z} j_{\mathrm{NO}_{2}^{-}, z} \mathrm{~d} z,\end{aligned}$

with respectively $\left[\mathrm{NO}_{3}^{-}\right]_{\mathrm{z}}$ and $\left[\mathrm{NO}_{2}^{-}\right]_{\mathrm{z}}$ in molecule $\mathrm{cm}^{-3}$ measured at each depth $z$ (Fig. 6).

In order to convert flux $F_{\mathrm{NO}_{\mathrm{x}}}\left(\right.$ molecule $\left.\mathrm{cm}^{-2} \mathrm{~s}^{-1}\right)$ into a volumetric production rate $P_{\mathrm{NO}_{\mathrm{x}}}\left(\mathrm{pptvh}^{-1}\right), F_{\mathrm{NO}_{\mathrm{x}}}$ was multiplied by the height of the boundary layer estimated from prior balloon soundings above the West Antarctic Ice Sheet in summer, with an average height of $250 \mathrm{~m}$ (range 13-354 m) between morning and late afternoon (Frey et al., 2005). Note that atmospheric boundary layer height as low as $13 \mathrm{~m}$ may be infrequent at WAIS Divide. Therefore, estimation of the potential $\mathrm{NO}_{\mathrm{x}}$ production from snow for an atmospheric boundary layer height of $13 \mathrm{~m}$ will be an upper bound.

Recent studies (Chu and Anastasio, 2007; Boxe and SaizLopez, 2008, and references therein) suggest that only $\mathrm{NO}_{3}^{-}$ and $\mathrm{NO}_{2}^{-}$in quasi-liquid layers are available for photolysis as photochemistry of these species does not occur in the bulk ice. Because the distribution of $\mathrm{NO}_{3}^{-}$and $\mathrm{NO}_{2}^{-}$between the quasi-liquid layers and the lattice ice is unknown, these calculations assumed that all $\mathrm{NO}_{3}^{-}$and $\mathrm{NO}_{2}^{-}$can be photolyzed. It is also assumed that the totality of the $\mathrm{NO}_{\mathrm{x}}$ produced escapes from the snowpack and is released into the overlying atmosphere without considering any chemical loss. These fluxes and production rates are therefore an upper limit of the potential $\mathrm{NO}_{\mathrm{x}}$ source from the snow.

\subsubsection{Potential $\mathrm{NO}_{\mathrm{x}}$ production from top snowpack}

The resulting potential daily $\mathrm{NO}_{2}$ emission fluxes from $\mathrm{NO}_{3}^{-}$photolysis in the surface snowpack were $8.6 \times 10^{8}$ molecule $\mathrm{cm}^{-2} \mathrm{~s}^{-1}$ (Table 3). This value is in agreement with previous reported $\mathrm{NO}_{2}$ emission fluxes on the Antarctic continent (Table 4). For NO, the estimated value is $33.9 \times 10^{8}$ molecule $\mathrm{cm}^{-2} \mathrm{~s}^{-1}$. Maximum daily $\mathrm{NO}_{\mathrm{x}}$ emission fluxes from snow are therefore $F_{\mathrm{NO}}$ of $42.5 \times 10^{8}$ molecule $\mathrm{cm}^{-2} \mathrm{~s}^{-1}$, with $20 \%$ and $80 \%$ from 
Table 3. Potential depth integrated $\mathrm{NO}_{\mathrm{x}}$ emission fluxes and equivalent $\mathrm{NO}_{\mathrm{x}}$ production rates from $\mathrm{NO}_{3}^{-}$and $\mathrm{NO}_{2}^{-}$photolysis for an $\mathrm{EFD}$ of $30 \mathrm{~cm}$, a solar elevation angle of $23^{\circ}$ and three different atmospheric boundary layer heights (ABL) from previous measurements (Frey et al., 2005).

\begin{tabular}{lcccc}
\hline Compound & Potential emission fluxes & \multicolumn{3}{c}{ Potential production rates $\left(\mathrm{pptvh}^{-1}\right)$} \\
\cline { 3 - 5 } & $\left(10^{8}\right.$ molecule $\left.\mathrm{cm}^{-2} \mathrm{~s}^{-1}\right)$ & $\mathrm{ABL}=13 \mathrm{~m}$ & $\mathrm{ABL}=250 \mathrm{~m}$ & $\mathrm{ABL}=354 \mathrm{~m}$ \\
\hline $\mathrm{NO}_{2}$ & 8.6 & 114 & 6 & 4 \\
$\mathrm{NO}$ & 33.9 & 452 & 24 & 17 \\
\hline
\end{tabular}

$\mathrm{NO}_{3}^{-}$and $\mathrm{NO}_{2}^{-}$photolysis, respectively. This contribution is similar to that found by France et al. (2012) at Barrow.

The resulting local $\mathrm{NO}_{\mathrm{x}}$ production is $30 \mathrm{pptvh}^{-1}$ for a mean atmospheric boundary layer height of $250 \mathrm{~m}$ (Table 3 ). Average production rates of 21 and $566 \mathrm{pptvh}^{-1}$ were calculated for boundary layer depths of 354 and $13 \mathrm{~m}$, respectively. Comparison between the potential $\mathrm{NO}_{\mathrm{x}}$ production rate and the mixing ratios of $\mathrm{NO}_{\mathrm{x}}$ estimated from the extended Leighton mechanism with measured NO (Sect. 4.1.3) indicates that the snow source contributes significantly to the $\mathrm{NO}_{\mathrm{x}}$ budget at WAIS Divide. However, values of $P_{\mathrm{NO}_{\mathrm{x}}}$ suggest that the estimated production rates are an upper limit since the observed levels of NO (19 pptv) and the estimated $\mathrm{NO}_{2}$ mixing ratios (5 pptv) are inconsistent with an $\mathrm{NO}_{\mathrm{x}}$ production rate of $566 \mathrm{pptvh}^{-1}$ for atmospheric boundary layer height of $13 \mathrm{~m}$.

These calculated $\mathrm{NO}_{\mathrm{x}}$ emissions are higher than reported values from other Antarctic sites, where modeled and measured fluxes reached between $2.4 \times 10^{8}$ and $22 \times 10^{8}$ molecule $\mathrm{cm}^{-2} \mathrm{~s}^{-1}$ (Table 4). In a recent study, Zatko et al. (2013) suggested that local contamination from nearby stations increases the content of impurities in snow, therefore reducing the EFD of the actinic flux in the top snowpack, resulting in a possible underestimation of the $\mathrm{NO}_{\mathrm{x}}$ emissions modeled or measured nearby stations by a factor of 1.4-2.4. Thus, high $\mathrm{NO}_{\mathrm{x}}$ emissions could be expected in our study since the sampling site was $5 \mathrm{~km}$ upwind of the main WAIS camp emissions (Sect. 2). However, the results from Zatko et al. (2013) can be discussed since most of the measurements or estimations of $\mathrm{NO}_{\mathrm{x}}$ nearby Antarctic stations were from sites located in clean air sector, upwind of the stations (Table 4). With said precautions, local contamination from nearby stations should not reach these sites and impact on the measured or calculated snowpack emissions.

The above estimates do have uncertainties: a) daily surface-snow samples revealed that the local-scale spatial variability of $\mathrm{NO}_{3}^{-}$in the near-surface snowpack is significant, and b) our calculations assume that all of the $\mathrm{NO}_{3}^{-}$and $\mathrm{NO}_{2}^{-}$in snow is available for photolysis followed by emission into the atmosphere of all the photo-produced NO and $\mathrm{NO}_{2}$. Concerning b), Anastasio and Chu (2009) suggested that $30 \%$ of the $\mathrm{NO}_{2}$ produced from $\mathrm{NO}_{3}^{-}$photolysis may be converted to $\mathrm{NO}_{2}^{-}$within the snow matrix before being released into the atmosphere. Also, the decrease of $5 \%$ per day of $\mathrm{NO}_{2}^{-}$in surface snow (Sect. 3.2) indicates that only a small amount of $\mathrm{NO}_{2}^{-}$may actually undergo photolysis to produce NO. Nevertheless, these results show the key role of the boundary-layer depth in determining the contribution of snowpack emissions to the overlying photochemistry. Our estimates imply that both the variability of boundary layer height with an observed range in summer of 13 to $354 \mathrm{~m}$ and local $\mathrm{NO}_{\mathrm{x}}$ emissions from snow impact the atmospheric $\mathrm{NO}_{\mathrm{x}}$ mixing ratios.

\subsubsection{Local production of $\mathrm{O}_{3}$}

The oxidation of methane is the main in situ chemical source of tropospheric $\mathrm{O}_{3}$. Thus, Reaction (R1) leads to production of $\mathrm{O}_{3}$ while Reaction (R13) leads to its destruction (Seinfeld and Pandis, 1998):

$\mathrm{HO}_{2}+\mathrm{O}_{3} \rightarrow \mathrm{OH}+2 \mathrm{O}_{2}$.

The ratio between theses two rates indicates whether WAIS Divide is an $\mathrm{O}_{3}$ production or destruction site:

$$
\frac{(\mathrm{R} 13)}{(\mathrm{R} 1)}=\frac{k_{\mathrm{R} 13}}{k_{\mathrm{R} 1}} \frac{\left[\mathrm{O}_{3}\right]}{[\mathrm{NO}]} \text {. }
$$

This ratio was calculated with $k_{\mathrm{R} 1}=$ $9.49 \times 10^{-12} \mathrm{~cm}^{3}$ molecule ${ }^{-1} \mathrm{~s}^{-1} \quad$ and $\quad k_{\mathrm{R} 13}=$ $1.62 \times 10^{-15} \mathrm{~cm}^{3}$ molecule ${ }^{-1} \mathrm{~s}^{-1}$, derived from Sander et al. (2006), and an average temperature of $255.6 \mathrm{~K}$ measured during the campaign. Note that this estimation from the photo stationary state relation accounts for the $\mathrm{NO}_{\mathrm{x}}$ emitted from the snowpack. In the case of Summit, Thomas et al. (2012) showed that $\mathrm{NO}_{\mathrm{x}}$ emitted from the snowpack can increase the boundary layer $\mathrm{O}_{3}$ by an additional 2-3 ppbv. Frey et al. (2013) show that under calm conditions typical for Dome C, East Antarctica, $\mathrm{NO}$ and $\mathrm{NO}_{2}$ emitted by surface snow reach steady-state at $1 \mathrm{~m}$. Thus, it is expected that our measured mixing ratios of $\mathrm{O}_{3}$ at $1 \mathrm{~m}$ above surface snow already reflect the contribution from the $\mathrm{NO}_{\mathrm{x}}$ emissions. Also, it is assumed that halogen chemistry does not occur at WAIS Divide, otherwise the reaction of $\mathrm{BrO}$ with $\mathrm{O}_{3}$ and $\mathrm{NO}_{\mathrm{x}}$ in the snowpack would reduce the local $\mathrm{O}_{3}$ production (Thomas et al., 2012).

The ratio (R13):(R1) equals 0.216 and confirms that WAIS Divide is a surface ozone production site (Sect. 4.1.1). 
Table 4. Potential emission flux of $\mathrm{NO}_{\mathrm{x}}$ from $\mathrm{NO}_{3}^{-}$and $\mathrm{NO}_{2}^{-}$photolysis in snow at WAIS Divide compared to other Antarctic sites.

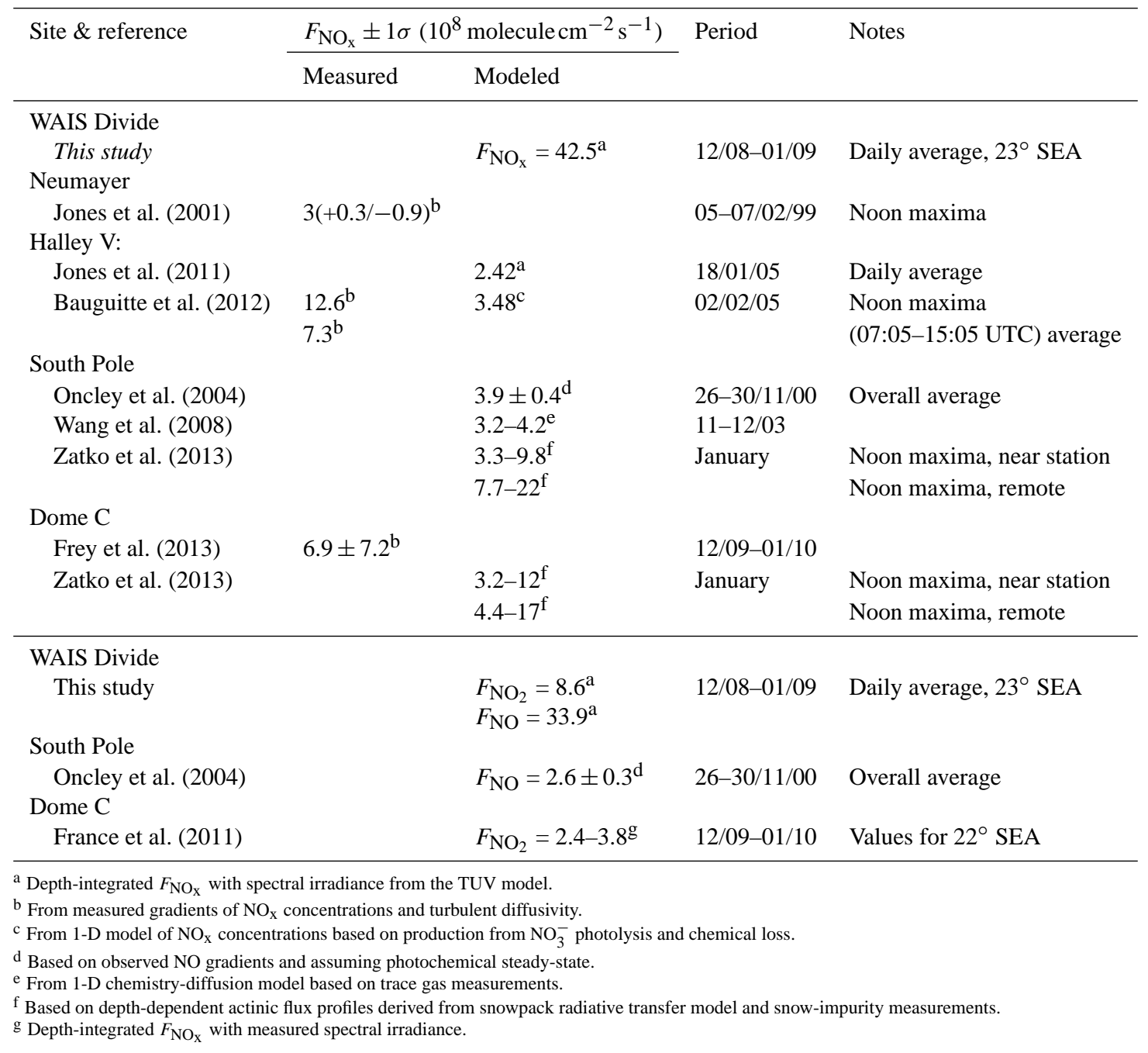

From Eq. (7), a threshold value of 2 pptv for NO is found to trigger $\mathrm{O}_{3}$ production at WAIS Divide, whereas this threshold is reached at 5 pptv in the remote continental troposphere of mid-latitude regions (Seinfeld and Pandis, 1998) and of high latitude sites, such as Dome $\mathrm{C}$ (derived from Chen et al., 2007). An atmospheric $\mathrm{HO}_{2}$ concentration of $4.9 \times 10^{7}$ molecule $\mathrm{cm}^{-3}$ leads to a potential $\mathrm{O}_{3}$ production of 0.8 ppbv day $^{-1}$. This is about $5 \%$ of the observed $\mathrm{O}_{3}$ mixing ratios and respectively $20 \%$ and $50 \%$ of the rates calculated above the East Antarctic Plateau. $\mathrm{O}_{3}$ production rates are $\sim 4$ ppbv day $^{-1}$ at South Pole (Chen et al., 2004, and references therein) and $\sim 1.5 \mathrm{ppbv} d a y^{-1}$ at Dome $\mathrm{C}$ (Legrand et al., 2009). Our result is consistent with these previous studies since WAIS Divide is a lower-altitude site with a deeper atmospheric boundary layer that is influenced by a diel cycle of UV irradiance.

It is apparent that local $\mathrm{O}_{3}$ production is too small to account for the observed increases between 24-25 and 27-29
December of $0.3 \mathrm{ppbvh}^{-1}$. We therefore consider the impact of air mass transport, as detailed below.

\subsection{Impacts of air mass transport}

Analysis of wind direction and $\mathrm{O}_{3}$ mixing ratios indicate that air masses from the ENE-SWS sector have typically the highest $\mathrm{O}_{3}$ concentrations (Sect. 2, Fig. 4). $\mathrm{O}_{3}$ can be considered a long-lived chemical species compared to $\mathrm{NO}_{\mathrm{x}}$ (Sect. 4.1.5) with a lifetime of about 22 days in the polar regions (Grannas et al., 2007). It is therefore expected that local $\mathrm{O}_{3}$ is affected by transport, so the origin and transport of air at WAIS Divide were further investigated using 4-day back trajectories.

A total 168 trajectories were computed with the NOAA Hysplit(HYbrid Single-Particle Lagrangian Integrated Trajectory; see http://ready.arl.noaa.gov/hysplit4.html) model (R. R. Draxler and G. D. Rolph, 2003) every 4 h using global meteorological data from the NCEP Global Data Assimilation System (GDAS) with a $3 \mathrm{~h}$ temporal resolution, a 
$1^{\circ} \times 1^{\circ}$ (latitude $\times$ longitude) spatial resolution, an endpoint at the latitude and longitude of WAIS Divide and $10 \mathrm{~m}$ above ground level from 10 December 2008 to 8 January 2009. A comparison of the resulting 168 trajectories with another set generated from the NCEP-NCAR archived data shows similar results (Fig. 9), while Sinclair et al. (2013) showed that back trajectories from NCEP-NCAR and ECMWF Interim Re-Analysis (ERA-Interim) were comparable during austral summer. Therefore, the following discussion is based on trajectories produced from the GDAS archives. The back trajectories were combined to create daily maps (Fig. 10) and we distinguish three regions of air mass origin based on elevation, slope and previous $\mathrm{O}_{3}$ and temperature measurements (Fig. 9).

We refer to the East Antarctic Plateau as the East Antarctic region above $2500 \mathrm{~m}$ a.m.s.l. with a slope of less than $1^{\circ}$ since elevated $\mathrm{O}_{3}$ has not been observed below $2500 \mathrm{~m}$ a.m.s.l. during the Antarctic summer (Frey et al., 2005). Surface $\mathrm{O}_{3}$ is produced over the East Antarctic Plateau and possibly exported through air outflow (Sect. 4.2.2). The inner WAIS refers to the West Antarctic area above $1750 \mathrm{~m}$ a.m.s.l. with a slope inferior to $1^{\circ}$. An average temperature of about $-25^{\circ} \mathrm{C}$ was reported in the inner WAIS compared to $-15^{\circ} \mathrm{C}$ in the lower-elevated regions (Frey et al., 2005). Finally, based on a slope higher than $1^{\circ}$ and on the previous observations, the areas below $2500 \mathrm{~m}$ a.m.s.l. in East Antarctica and 1750 m a.m.s.l. in West Antarctica are referred to as Antarctic coastal slopes.

Figure 9 shows that over the campaign, $58 \%$ of the air masses originated from the Antarctic coastal slopes with $2 \%$ possibly flowing from the distant King Haakon VII coast. An estimated $17 \%$ was transported from the inner WAIS and $25 \%$ of the air was advected from the East Antarctic Plateau. About $71 \%$ of the air reaching WAIS Divide flowed from East Antarctica and 29\% from West Antarctica.

\subsubsection{Air mass origins related to low $\mathrm{O}_{3}$ levels}

Except for outflows from the East Antarctic Plateau, all air mass origins are associated with low $\mathrm{O}_{3}$, averaging $13 \pm 3$ ppbv (Fig. 11). This represents therefore $75 \%$ of the air mass reaching WAIS Divide, which includes air from the coastal slopes (Fig. 10a, b) and the inner WAIS (Fig. 10e). In coastal Antarctica, halogen-catalyzed chemistry has been found to prevent $\mathrm{O}_{3}$ production in summer and even leads to the well-known episodic $\mathrm{O}_{3}$ depletion events during spring (Jones et al., 2008, and references therein). The little verticalcolumn amounts of IO and $\mathrm{BrO}$ observed at WAIS Divide from satellite in December and January 2004-2009 (Schönhardt et al., 2012) suggest that contribution of halogens from intrusions of coastal air (58\% of all back trajectories) to the WAIS Divide photochemistry is not significant. Thus, reduction of $\mathrm{O}_{3}$ levels at WAIS Divide by halogen chemistry may not occur, as assumed in the previous sections.

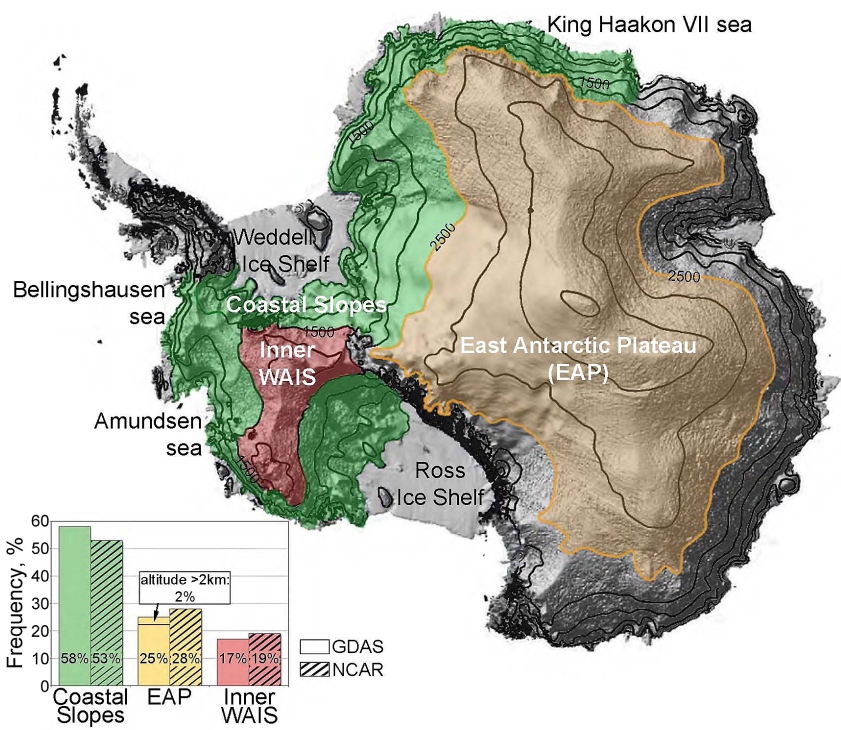

Fig. 9. Map of the different origins of air reaching WAIS Divide identified by the 4-day back-trajectory analysis and topography: East Antarctic Plateau (yellow), inner WAIS (red) and the Antarctic coastal slopes (green). Comparison between the results from analyses using the GDAS and NCAR meteorological archived data is shown.

Air masses from the interior of WAIS (17\% of all back trajectories, Fig. 10e) are also associated with low $\mathrm{O}_{3}$ mixing ratios. Influence from local halogen chemistry or halogens exported from the Antarctic coasts is not consistent with observations of Schönhardt et al. (2012).

It is therefore suggested that the $\mathrm{O}_{3}$ levels of the air masses from the coastal slopes and the interior of WAIS are low, so these airflows can reduce the $\mathrm{O}_{3}$ levels of WAIS Divide when reaching the site. From these results and the windspeed record (Fig. 11), it is also expected that $\mathrm{O}_{3}$ production over WAIS is less than or equal to our estimated $\mathrm{O}_{3}$ production rate for WAIS Divide.

Airflows from long-distance sources such as King Haakon VII sea coast ( $2 \%$ of all back trajectories, Fig. 10f) appear infrequently, with no obvious impact on local $\mathrm{O}_{3}$. The $\mathrm{O}_{3}$ signature of these air masses likely disappeared during their transport over more than $2500 \mathrm{~km}$.

\subsubsection{Air mass origins associated with elevated $\mathrm{O}_{3}$ levels}

Approximately $25 \%$ of all back trajectories point to airflows from the East Antarctic Plateau (Fig. 10c, d and Fig. 9), which are mainly related to the highest $\mathrm{O}_{3}$ measured at WAIS Divide, with an average $\pm 1 \sigma$ of $19 \pm 4$ ppbv (Fig. 11).

This is consistent with the $\mathrm{O}_{3}$ production above the East Antarctic Plateau (Helmig et al., 2008a, and references therein) that enhances the $\mathrm{O}_{3}$ levels of WAIS through air transport, as previously reported by Legrand et al. (2009), who only observed high $\mathrm{O}_{3}$ mixing ratios at Dumont 


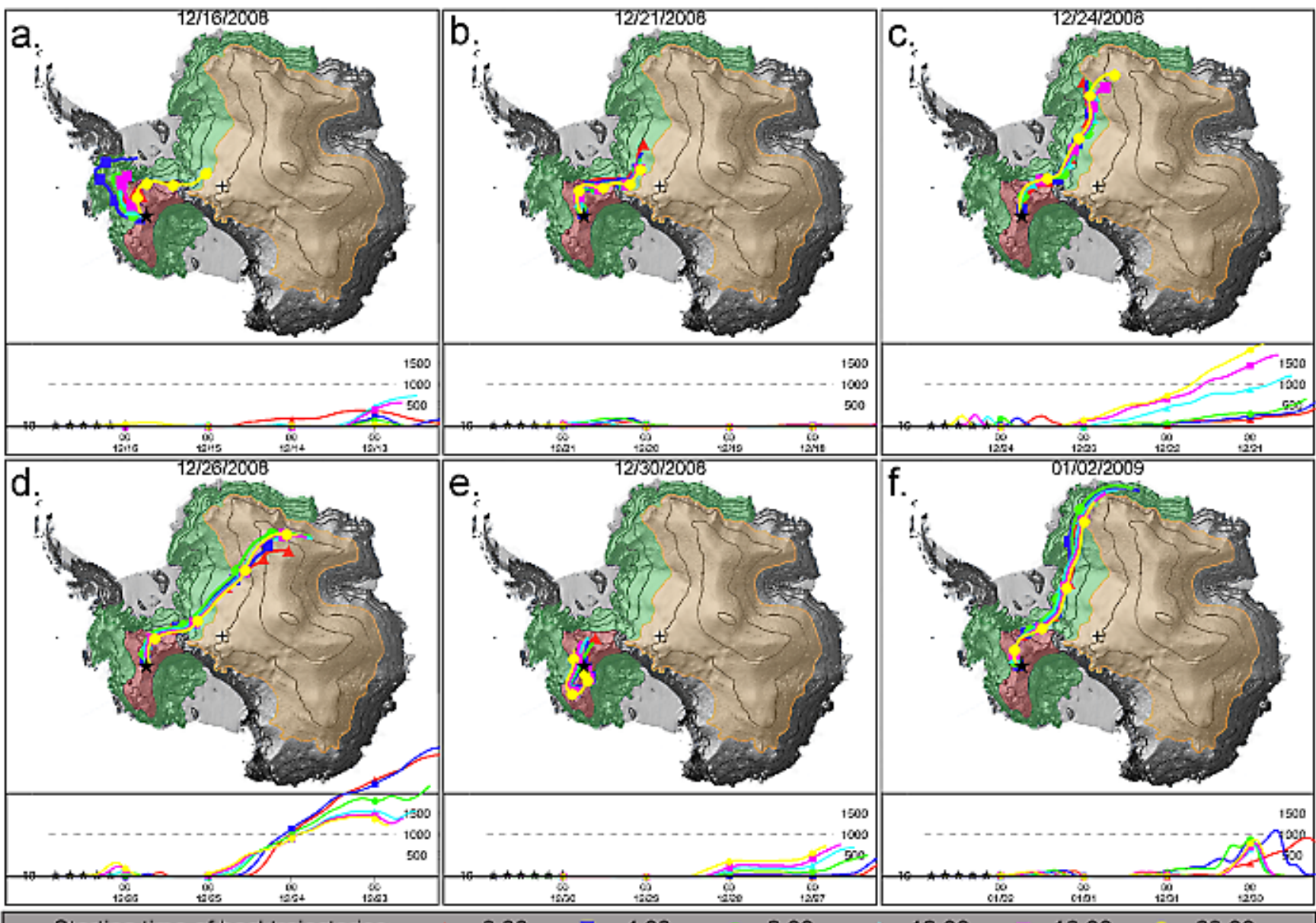

Starting time of backtrajectories: $\rightarrow-0: 00 \rightarrow-4: 00$

$8: 00$

Fig. 10. Combined 4-day back-trajectory maps of some specific events identified in Fig. 11. Each daily map contains 6 trajectories of 4-hour intervals and symbols are plotted for every $24 \mathrm{~h}$ time step. The different regions of air origin are identified in Fig. 9. Trajectory colors do not correspond to map colors. Trajectory elevations are meters above ground level.

D'Urville for air masses originating from the Antarctic Plateau. Such an oxidizing environment is confirmed by the $\mathrm{O}_{3}$ observations at South Pole (S. J. Oltmans, http://ds.data. jma.go.jp/gmd/wdcgg) over the same period that shows an average concentration of $31 \mathrm{ppbv}, 17 \mathrm{ppbv}$ more than the average observed at WAIS Divide (Fig. 11).

Further back-trajectory analysis reveals two conditions in which high $\mathrm{O}_{3}$ concentrations are observed above WAIS Divide. First, elevated $\mathrm{O}_{3}$ mixing ratios were only observed for lower atmosphere air coming from the East Antarctic Plateau (below $1500 \mathrm{~m}$ above ground level). The trajectories of these near-surface airflows are in good agreement with the katabatic streamlines described by Parish and Bromwich (2007). This suggests that air exported off the East Antarctic Plateau via katabatic outflows raises significantly the $\mathrm{O}_{3}$ mixing ratios at WAIS Divide. The ozone depletion recorded between 25 and 27 December 2008 (Fig. 10d and Fig. 11) is attributed to an air mass coming from altitude as high as $\sim 3000 \mathrm{~m}$ above ground level.
Secondly, high $\mathrm{O}_{3}$ was only observed at WAIS Divide when the transport time from the East Antarctic Plateau was less than 3 days (Fig. 10c and d). To investigate this condition, the total $\mathrm{O}_{3}$ loss during transport from the Antarctic Plateau to WAIS Divide was estimated. The back trajectories indicate that $\mathrm{O}_{3}$ maxima during 24-28 December at WAIS Divide are due to rich $\mathrm{O}_{3}$ air originating from the South Pole region, as local records show similar but higher peaks about 2 days before (Fig. 11). From this delay, a loss rate of 0.25 $( \pm 0.04) \mathrm{ppbvh}^{-1}$ was calculated. This represents an $\mathrm{O}_{3}$ loss rate of $5.5( \pm 0.9)$ ppbv day $^{-1}$ when averaged $\mathrm{O}_{3}$ mixing ratios were 30 and $14 \mathrm{ppbv}$, respectively, at South Pole and WAIS Divide over the campaign. If these loss rates (from dilution, net destruction, etc.) are typical, then it follows that $\mathrm{O}_{3}$ export off the Plateau has to be rapid (less than 3 days) in order to have an impact on WAIS Divide's levels.

Observations of elevated $\mathrm{O}_{3}$ levels are frequently related to vertical transport from the free troposphere/lower stratosphere at Summit, Greenland (Helmig et al., 2007b) and 


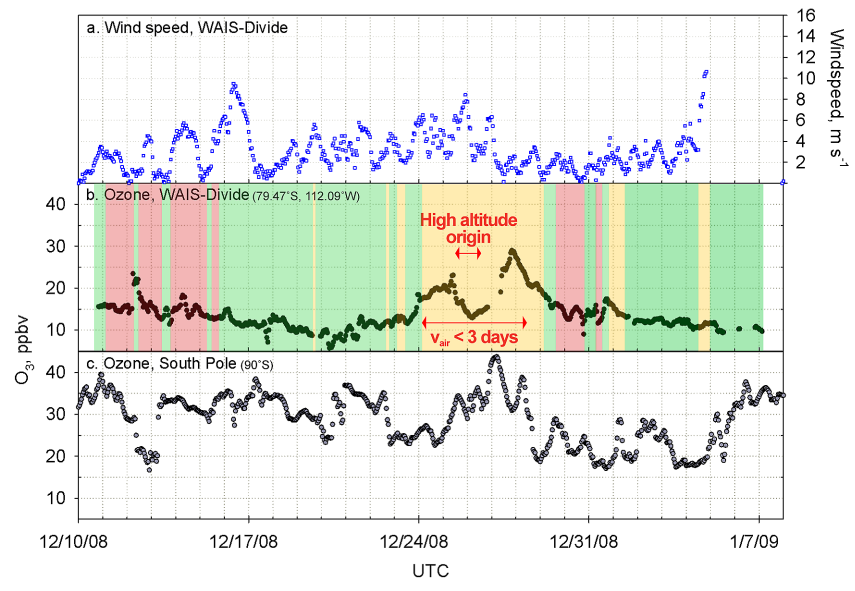

Fig. 11. The $1 \mathrm{~h}$ averages of observed (a) wind speed at WAIS Divide, (b) $\mathrm{O}_{3}$ at WAIS Divide, and (c) $\mathrm{O}_{3}$ at South Pole (data available at: http://ds.data.jma.go.jp/gmd/wdcgg) for austral summer 2008-2009. Air mass origins are reported with the identical color coding used in Fig. 9: East Antarctic Plateau (yellow), inner WAIS (red) and Antarctic coastal slopes (green). Events of air transport less than 3 days between East Antarctic Plateau and WAIS Divide $\left(v_{\text {air }}<3\right.$ days $)$ and of high-altitude air origin $(<2 \mathrm{~km}$ above ground level) are also reported.

other Arctic sites (Helmig et al., 2007a, and references therein). These stratospheric-intrusion events are promoted by boundary-layer instabilities, which are caused by significant diel radiation cycles and by the size of the Greenland ice sheet (Helmig et al., 2007b). All of the vertical $\mathrm{O}_{3}$ profiles over the East Antarctic Plateau from tetheredballoon measurements (Helmig et al., 2008a; Johnson et al., 2008; Oltmans et al., 2008) and an airborne study (Slusher et al., 2010) present higher $\mathrm{O}_{3}$ mixing ratios in the atmospheric boundary layer than in the free troposphere, indicating that no contribution of stratospheric $\mathrm{O}_{3}$ occurs over the Antarctic Plateau. Enhancement of the $\mathrm{O}_{3}$ levels at WAIS Divide from vertical transport is neither supported by the back-trajectory analysis nor by the vertical $\mathrm{O}_{3}$ profiles measured at South Pole during this period (http://www.esrl.noaa.gov/gmd/dv/data/index.php), confirming the previous observations from the East Antarctic Plateau.

However, not all elevated $\mathrm{O}_{3}$ mixing ratios at this site could be explained with the air origin. This is the case for the $5 \mathrm{~h}$ rise of $\mathrm{O}_{3}$ mixing ratios that reached $24 \mathrm{ppbv}$ on 12 December and occurred during the only snowfall observed during the campaign (Fig. 5). With low wind speeds (Fig. 11) and airflow from the inner WAIS observed during this event, it is possible that more $\mathrm{O}_{3}$ accumulated in the boundary layer from local production. However, given the $\mathrm{O}_{3}$ production rate we estimated previously (Sect. 4.1.7), it seems unlikely that only the local production of $\mathrm{O}_{3}$ could cause this specific increase.

\section{Conclusions}

Being from a geographically intermediate site between the Antarctic coast and the East Antarctic Plateau, our results show that concentrations of atmospheric $\mathrm{NO}, \mathrm{O}_{3}, \mathrm{H}_{2} \mathrm{O}_{2}$ and skin-layer $\mathrm{NO}_{3}^{-}$at WAIS Divide during summer 2008-2009 are similar to coastal levels.

Comparison of local potential $\mathrm{NO}_{\mathrm{x}}$ production from daily average depth-integrated emission fluxes of $\mathrm{NO}_{\mathrm{x}}$ and the $\mathrm{NO}_{\mathrm{x}}$ mixing ratios estimated from a steady-state assumption shows that $\mathrm{NO}_{3}^{-}$and $\mathrm{NO}_{2}^{-}$photolysis in the local snowpack are a significant source of $\mathrm{NO}_{\mathrm{x}}$ at WAIS Divide. The upper limit of $15 \mathrm{~h} \mathrm{NO}_{\mathrm{x}}$ lifetime confirms that short-lived $\mathrm{NO}_{\mathrm{x}}$ species are more sensitive to local production above WAIS than to outflows from the East Antarctic Plateau. Lower $\mathrm{NO}_{3}^{-}$ preservation in snow at WAIS Divide than at Summit is coherent with the potential $\mathrm{NO}_{\mathrm{x}}$ emission flux and suggests stronger lateral export of emitted $\mathrm{NO}_{\mathrm{x}}$ than local recycling.

$\mathrm{O}_{3}$ production at WAIS Divide can be triggered with $\mathrm{NO}$ mixing ratios higher than 2 pptv, but the small $\mathrm{O}_{3}$ production rate cannot explain the observed $\mathrm{O}_{3}$ variability, which suggests a significant air mass transport contribution. Air flows from the East Antarctic Plateau are only associated with high $\mathrm{O}_{3}$ mixing ratios if the air transport is near surface by gravity driven winds and less than 3 days from the East Antarctic Plateau. With levels of $\mathrm{O}_{3}$ over the East Antarctic Plateau twice those observed at WAIS Divide, outflows from the interior of the continent therefore have the potential to enhance the mixing ratios of long-lived atmospheric chemical species such as $\mathrm{O}_{3}$ over WAIS. During this 28-day campaign, outflows from the Antarctic Plateau were observed over 7.5 days, raising the summer $\mathrm{O}_{3}$ average by about $20 \%$ ( 2 ppbv). The possibility of halogen chemistry above inland WAIS that would impact the atmospheric photochemistry is not consistent with satellite observations and cannot therefore explain the low $\mathrm{O}_{3}$ levels that are associated with air mass origins from the interior of WAIS.

Results from the back-trajectory analysis over December 2008 and January 2009 at WAIS Divide (Fig. 9) compare well with those of Markle et al. (2012) calculated over thirty years in the Ross Sea region. For the same months, the authors found that $45 \%$ of the air mass trajectories have an oceanic/West Antarctic origin and $55 \%$ a continental/East Antarctic source, while we observed respective values of $29 \%$ and $71 \%$ at WAIS Divide. These results confirm the minor contribution of oceanic/West Antarctic inflows to the WAIS atmosphere during austral summer shown by Nicolas and Bromwich (2011), and the predominance of continental/East Antarctic air masses that may significantly impact the oxidative capacity of the atmosphere above the interior of WAIS. 
Acknowledgements. This work was supported by the National Science Foundations Office of Polar Programs (OPP-0636929). We thank G. Huey for the use of the nitric oxide detector. We also thank S. J. Oltmans for using his $\mathrm{O}_{3}$ measurements from South Pole, as well as B. Alexander and E. D. Sofen for their insight concerning the EFD and $\mathrm{NO}_{3}^{-}$photolysis at WAIS Divide.

Edited by: J. W. Bottenheim

\section{References}

Anastasio, C. and Chu, L.: Photochemistry of Nitrous Acid (HONO) and Nitrous Acidium Ion $\left(\mathrm{H}_{2} \mathrm{ONO}^{+}\right)$in Aqueous Solution and Ice, Environ. Sci. Technol., 43, 1108-1114, doi:10.1021/es802579a, 2009.

Anastasio, C. and Robles, T.: Light absorption by soluble chemical species in Arctic and Antarctic snow, J. Geophys. Res.-Atmos., 112, D24304, doi:10.1029/2007JD008695, 2007.

Banta, J. R., Mcconnell, J. R., Frey, M. M., Bales, R. C., and Taylor, K.: Spatial and temporal variability in snow accumulation at the West Antarctic Ice Sheet Divide over recent centuries, J. Geophys. Res., 113, D23102, doi:10.1029/2008JD010235, 2008.

Bauguitte, S. J.-B., Brough, N., Frey, M. M., Jones, A. E., Maxfield, D. J., Roscoe, H. K., Rose, M. C., and Wolff, E. W.: A network of autonomous surface ozone monitors in Antarctica: technical description and first results, Atmos. Meas. Tech., 4, 645-658, doi:10.5194/amt-4-645-2011, 2011.

Bauguitte, S. J.-B., Bloss, W. J., Evans, M. J., Salmon, R. A., Anderson, P. S., Jones, A. E., Lee, J. D., Saiz-Lopez, A., Roscoe, H. K., Wolff, E. W., and Plane, J. M. C.: Summertime $\mathrm{NO}_{\mathrm{x}}$ measurements during the CHABLIS campaign: can source and sink estimates unravel observed diurnal cycles?, Atmos. Chem. Phys., 12, 989-1002, doi:10.5194/acp-12-989-2012, 2012.

Bisiaux, M. M., Edwards, R., McConnell, J. R., Curran, M. A. J., Van Ommen, T. D., Smith, A. M., Neumann, T. A., Pasteris, D. R., Penner, J. E., and Taylor, K.: Changes in black carbon deposition to Antarctica from two high-resolution ice core records, 1850-2000 AD, Atmos. Chem. Phys., 12, 4107-4115, doi:10.5194/acp-12-4107-2012, 2012.

Bloss, W. J., Lee, J. D., Heard, D. E., Salmon, R. A., Bauguitte, S. J.-B., Roscoe, H. K., and Jones, A. E.: Observations of $\mathrm{OH}$ and $\mathrm{HO}_{2}$ radicals in coastal Antarctica, Atmos. Chem. Phys., 7, 4171-4185, doi:10.5194/acp-7-4171-2007, 2007.

Boxe, C. S. and Saiz-Lopez, A.: Multiphase modeling of nitrate photochemistry in the quasi-liquid layer (QLL): implications for $\mathrm{NO}_{\mathrm{x}}$ release from the Arctic and coastal Antarctic snowpack, Atmos. Chem. Phys., 8, 4855-4864, doi:10.5194/acp-8-4855-2008, 2008.

Burkhart, J. F., Hutterli, M. A., Bales, R. C., and Mcconnell, J. R.: Seasonal accumulation timing and preservation of nitrate in firn at Summit, Greenland, J. Geophys. Res.-Atmos., 109, D19302, doi:10.1029/2004JD004658, 2004.

Chen, G., Davis, D. D., Crawford, J. H., Hutterli, M. A., Huey, G., Slusher, D., Mauldin, L., Eisele, F., Tanner, D., Dibb, J. E., Buhr, M., Mcconnell, J. R., Lefer, B., Shetter, R., Blake, D. R., Song, C., Lombardi, K., and Arnoldy, J.: A reassessment of $\mathrm{HO}_{\mathrm{x}}$ South Pole chemistry based on observations recorded during ISCAT 2000, Atmos. Environ., 38, 5451-5461, 2004.
Chen, G., Huey, G., Crawford, J. H., Olson, J. R., Hutterli, M. A., Sjostedt, S. J., Tanner, D., Dibb, J. E., Lefer, B., Blake, N. J., Davis, D. D., and Stohl, A.: An assessment of the polar $\mathrm{HO}_{\mathrm{x}}$ photochemical budget based on 2003 Summit Greenland field observations, Atmos. Environ., 41, 7806-7820, doi:10.1016/j.atmosenv.2003.07.018, 2007.

Chu, L. and Anastasio, C.: Quantum yields of hydroxyl radical and nitrogen dioxide from the photolysis of nitrate on ice, J. Phys. Chem. A, 107, 9594-9602, doi:10.1021/jp0349132, 2003.

Chu, L. and Anastasio, C.: Temperature and wavelength dependence of nitrite photolysis in frozen and aqueous solutions, Environ. Sci. Technol., 41, 3626-3632, doi:10.1021/es062731q, 2007.

Davis, D. D., Nowak, J., Chen, G., Buhr, M., Arimoto, R., Hogan, A., Eisele, F., Mauldin, L., Tanner, D., Shetter, R., Lefer, B., and McMurry, P.: Unexpected high levels of NO observed at South Pole, Geophys. Res. Lett., 28, 3625-3628, doi:10.1029/2000GL012584, 2001.

Davis, D. D., Chen, G., Buhr, M., Crawford, J. H., Lenschow, D., Lefer, B., Shetter, R., Eisele, F., Mauldin, L., and Hogan, A.: South Pole $\mathrm{NO}_{\mathrm{x}}$ chemistry: an assessment of factors controlling variability and absolute levels, Atmos. Environ., 38, 5375-5388, doi:10.1016/j.atmosenv.2004.04.039, 2004.

Davis, D. D., Seelig, J., Huey, G., Crawford, J. H., Chen, G., Wang, Y., Buhr, M., Helmig, D., Neff, W., Blake, D. R., Arimoto, R., and Eisele, F.: A reassessment of Antarctic plateau reactive nitrogen based on ANTCI 2003 airborne and ground based measurements, Atmos. Environ., 42, 2831-2848, doi:10.1016/j.atmosenv.2007.07.039, 2008.

Dibb, J. E., Huey, G., Slusher, D., and Tanner, D.: Soluble reactive nitrogen oxides at South Pole during ISCAT 2000, Atmos. Environ., 38, 5399-5409, 2004.

Dibb, J. E., Whitlow, S. I., and Arsenault, M.: Seasonal variations in the soluble ion content of snow at Summit. Greenland: Constraints from three years of daily surface snow samples, Atmos. Environ., 41, 5007-5019, doi:10.1016/j.atmosenv.2003.01.001, 2007.

Dibb, J. E., Ziemba, L. D., Luxford, J., and Beckman, P.: Bromide and other ions in the snow, firn air, and atmospheric boundary layer at Summit during GSHOX, Atmos. Chem. Phys., 10, 99319942, doi:10.5194/acp-10-9931-2010, 2010.

Domine, F., Albert, M., Huthwelker, T., Jacobi, H.-W., Kokhanovsky, A. A., Lehning, M., Picard, G., and Simpson, W. R.: Snow physics as relevant to snow photochemistry, Atmos. Chem. Phys., 8, 171-208, doi:10.5194/acp-8-171-2008, 2008.

Eisele, F. L. and Davis, D. D.: Antarctic tropospheric chemistry investigation (ANTCI) 2003, Atmos. Environ., 42, 2747-2748, doi:10.1016/j.atmosenv.2007.09.074, 2008.

Erbland, J., Vicars, W. C., Savarino, J., Morin, S., Frey, M. M., Frosini, D., Vince, E., and Martins, J. M. F.: Air-snow transfer of nitrate on the East Antarctic Plateau - Part 1: Isotopic evidence for a photolytically driven dynamic equilibrium in summer, Atmos. Chem. Phys., 13, 6403-6419, doi:10.5194/acp-136403-2013, 2013.

France, J., Reay, H., King, M., Voisin, D., Jacobi, H., Dominé, F., Beine, H., Anastasio, C., MacArthur, A., and Lee-Taylor, J.: Hydroxyl radical and $\mathrm{NO}_{\mathrm{x}}$ production rates, black carbon concentrations and light-absorbing impurities in snow from field 
measurements of light penetration and nadir reflectivity of onshore and offshore coastal Alaskan snow, J. Geophys. Res., 117, D00R12, doi:10.1029/2011JD016639, 2012.

France, J. L., King, M. D., Frey, M. M., Erbland, J., Picard, G., Preunkert, S., MacArthur, A., and Savarino, J.: Snow optical properties at Dome C (Concordia), Antarctica; implications for snow emissions and snow chemistry of reactive nitrogen, Atmos. Chem. Phys., 11, 9787-9801, doi:10.5194/acp-11-97872011, 2011.

Frey, M. M., Stewart, R. W., Mcconnell, J. R., and Bales, R. C.: Atmospheric hydroperoxides in West Antarctica: Links to stratospheric ozone and atmospheric oxidation capacity, J. Geophys. Res., 110, D23301, doi:10.1029/2005JD006110, 2005.

Frey, M. M., Bales, R. C., and Mcconnell, J. R.: Climate sensitivity of the century-scale hydrogen peroxide $\left(\mathrm{H}_{2} \mathrm{O}_{2}\right)$ record preserved in 23 ice cores from West Antarctica, J. Geophys. Res.-Atmos, 111, D21301, doi:10.1029/2005JD006816, 2006.

Frey, M. M., Hutterli, M. A., Chen, G., Sjostedt, S. J., Burkhart, J. F., Friel, D. K., and Bales, R. C.: Contrasting atmospheric boundary layer chemistry of methylhydroperoxide $\left(\mathrm{CH}_{3} \mathrm{OOH}\right)$ and hydrogen peroxide $\left(\mathrm{H}_{2} \mathrm{O}_{2}\right)$ above polar snow, Atmos. Chem. Phys., 9, 3261-3276, doi:10.5194/acp-9-3261-2009, 2009a.

Frey, M. M., Savarino, J., Morin, S., Erbland, J., and Martins, J. M. F.: Photolysis imprint in the nitrate stable isotope signal in snow and atmosphere of East Antarctica and implications for reactive nitrogen cycling, Atmos. Chem. Phys., 9, 8681-8696, doi:10.5194/acp-9-8681-2009, 2009b.

Frey, M. M., Brough, N., France, J. L., Anderson, P. S., Traulle, O., King, M. D., Jones, A. E., Wolff, E. W., and Savarino, J.: The diurnal variability of atmospheric nitrogen oxides (NO and $\mathrm{NO}_{2}$ ) above the Antarctic Plateau driven by atmospheric stability and snow emissions, Atmos. Chem. Phys., 13, 3045-3062, doi:10.5194/acp-13-3045-2013, 2013.

Grannas, A. M., Jones, A. E., Dibb, J., Ammann, M., Anastasio, C., Beine, H. J., Bergin, M., Bottenheim, J., Boxe, C. S., Carver, G., Chen, G., Crawford, J. H., Dominé, F., Frey, M. M., Guzmán, M. I., Heard, D. E., Helmig, D., Hoffmann, M. R., Honrath, R. E., Huey, L. G., Hutterli, M., Jacobi, H. W., Klán, P., Lefer, B., McConnell, J., Plane, J., Sander, R., Savarino, J., Shepson, P. B., Simpson, W. R., Sodeau, J. R., von Glasow, R., Weller, R., Wolff, E. W., and Zhu, T.: An overview of snow photochemistry: evidence, mechanisms and impacts, Atmos. Chem. Phys., 7, 43294373, doi:10.5194/acp-7-4329-2007, 2007.

Grilli, R., Legrand, M., Kukui, A., Méjean, G., Preunkert, S., and Romanini, D.: First investigations of $\mathrm{IO}, \mathrm{BrO}$, and $\mathrm{NO}_{2}$ summer atmospheric levels at a coastal East Antarctic site using modelocked cavity enhanced absorption spectroscopy, Geophys. Res. Lett., 40, 791-796, doi:10.1002/grl.50154, 2013.

Hastings, M. G.: Seasonal variations in $\mathrm{N}$ and $\mathrm{O}$ isotopes of nitrate in snow at Summit, Greenland: Implications for the study of nitrate in snow and ice cores, J. Geophys. Res., 109, D20306, doi:10.1029/2004JD004991, 2004.

Helmig, D., Oltmans, S. J., Carlson, D., Lamarque, J.-F., Jones, A. E., Labuschagne, C., Anlauf, K., and Hayden, K.: A review of surface ozone in the polar regions, Atmos. Environ., 41, 51385161, doi:10.1016/j.atmosenv.2006.09.053, 2007a.

Helmig, D., Oltmans, S. J., Morse, T. O., and Dibb, J. E.: What is causing high ozone at Summit, Greenland?, Atmos. Environ., 41, 5031-5043, doi:10.1016/j.atmosenv.2006.05.084, 2007b.
Helmig, D., Johnson, B., Oltmans, S. J., Neff, W., Eisele, F., and Davis, D. D.: Elevated ozone in the boundary layer at South Pole, Atmos. Environ., 42, 2788-2803, doi:10.1016/j.atmosenv.2006.12.032, 2008.

Honrath, R., Lu, Y., Peterson, M., Dibb, J., Arsenault, M., Cullen, N., and Steffen, K.: Vertical fluxes of $\mathrm{NO}_{\mathrm{x}}, \mathrm{HONO}$, and $\mathrm{HNO}_{3}$ above the snowpack at Summit, Greenland, Atmos. Environ., 36, 2629-2640, doi:10.1016/S1352-2310(02)00132-2, 2002.

Hutterli, M. A.: Sensitivity of hydrogen peroxide $\left(\mathrm{H}_{2} \mathrm{O}_{2}\right)$ and formaldehyde $(\mathrm{HCHO})$ preservation in snow to changing environmental conditions: Implications for ice core records, J. Geophys. Res., 108, 4023, doi:10.1029/2002JD002528, 2003.

Jacobi, H.-W., Weller, R., Jones, A. E., Anderson, P. S., and Schrems, O.: Peroxyacetyl nitrate (PAN) concentrations in the Antarctic troposphere measured during the photochemical experiment at Neumayer (PEAN'99), Atmos. Environ., 34, 52355247, doi:10.1016/S1352-2310(00)00190-4, 2000.

Jarvis, J. C., Hastings, M. G., Steig, E. J., and Kunasek, S. A.: Isotopic ratios in gas-phase $\mathrm{HNO}_{3}$ and snow nitrate at Summit, Greenland, J. Geophys. Res., 114, D17301, doi:10.1029/2009JD012134, 2009.

Jefferson, A., Tanner, D., Eisele, F., Davis, D., Chen, G., Crawford, J., Huey, J., Torres, A., and Berresheim, H.: OH photochemistry and methane sulfonic acid formation in the coastal Antarctic boundary layer, J. Geophys. Res.-Atmos., 103, 1647-1656, doi:10.1029/97JD02376, 1998.

Johnson, B., Helmig, D., and Oltmans, S. J.: Evaluation of ozone measurements from a tethered balloon-sampling platform at South Pole Station in December 2003, Atmos. Environ., 42, 2780-2787, doi:10.1016/j.atmosenv.2007.03.043, 2008.

Jones, A., Weller, R., Minikin, A., Wolff, E., Sturges, W., McIntyre, H., Leonard, S., Schrems, O., and Bauguitte, S.: Oxidized nitrogen chemistry and speciation in the Antarctic troposphere, J. Geophys. Res.-Atmos., 104, 21355-21366, doi:10.1029/1999JD900362, 1999.

Jones, A., Weller, R., Anderson, P., Jacobi, H., Wolff, E., Schrems, O., and Miller, H.: Measurements of $\mathrm{NO}_{\mathrm{x}}$ emissions from the Antarctic snowpack, Geophys. Res. Lett., 28, 1499-1502, doi:10.1029/2000GL011956, 2001.

Jones, A. E., Weller, R., Wolff, E. W., and Jacobi, H.-W.: Speciation and rate of photochemical $\mathrm{NO}$ and $\mathrm{NO}_{2}$ production in Antarctic snow, Geophys. Res. Lett., 27, 345-348, doi:10.1029/1999GL010885, 2000.

Jones, A. E., Wolff, E. W., Salmon, R. A., Bauguitte, S. J.-B., Roscoe, H. K., Anderson, P. S., Ames, D., Clemitshaw, K. C., Fleming, Z. L., Bloss, W. J., Heard, D. E., Lee, J. D., Read, K. A., Hamer, P., Shallcross, D. E., Jackson, A. V., Walker, S. L., Lewis, A. C., Mills, G. P., Plane, J. M. C., Saiz-Lopez, A., Sturges, W. T., and Worton, D. R.: Chemistry of the Antarctic Boundary Layer and the Interface with Snow: an overview of the CHABLIS campaign, Atmos. Chem. Phys., 8, 3789-3803, doi:10.5194/acp-8-3789-2008, 2008.

Jones, A. E., Wolff, E. W., Ames, D., Bauguitte, S. J.-B., Clemitshaw, K. C., Fleming, Z., Mills, G. P., Saiz-Lopez, A., Salmon, R. A., Sturges, W. T., and Worton, D. R.: The multi-seasonal $\mathrm{NO}_{\mathrm{y}}$ budget in coastal Antarctica and its link with surface snow and ice core nitrate: results from the CHABLIS campaign, Atmos. Chem. Phys., 11, 9271-9285, doi:10.5194/acp-11-92712011, 2011. 
Kreutz, K. and Koffman, B.: WAIS Divide Snowpit Chemical and Isotope Measurements, Antarctica, Boulder, Colorado USA: National Snow and Ice Data Center, 2011.

Kreutz, K. J., Mayewski, P. A., Twickler, M. S., Whitlow, S. I., White, J., Shuman, C. A., Raymond, C. F., Conway, H., and McConnell, J. R.: Seasonal variations of glaciochemical, isotopic and stratigraphic properties in Siple Dome (Antarctica) surface snow, Ann. Glaciol., 29, 38-44, doi:10.3189/172756499781821193, 1999.

Lee-Taylor, J. and Madronich, S.: Calculation of actinic fluxes with a coupled atmosphere-snow radiative transfer model, J. Geophys. Res.-Atmos., 107, 4796, doi:10.1029/2002JD002084, 2002.

Legrand, M., Preunkert, S., Jourdain, B., Gallée, H., Goutail, F., Weller, R., and Savarino, J.: Year-round record of surface ozone at coastal (Dumont d'Urville) and inland (Concordia) sites in East Antarctica, J. Geophys. Res., 114, D20306, doi:10.1029/2008JD011667, 2009.

Legrand, M. R. and Delmas, R. J.: Soluble impurities in four Antarctic ice cores over the last 30,000 years, Ann. Glaciol., 10, 116-120, 1988.

Lind, J. A. and Kok, G. L.: Correction to Henry's law determinations for aqueous solutions of hydrogen peroxide, methylhydroperoxide, and peroxyacetic acid, J. Geophys. Res., 99, 21119 21119, doi:10.1029/94JD01155, 1994.

Markle, B. R., Bertler, N. A. N., Sinclair, K. E., and Sneed, S. B.: Synoptic variability in the Ross Sea region, Antarctica, as seen from back-trajectory modeling and ice core analysis, J. Geophys. Res., 117, D02113,doi:10.1029/2011JD016437, 2012.

Mauldin, L., Kosciuch, E., Henry, B., Eisele, F., Shetter, R., Lefer, B., Chen, G., Davis, D. D., Huey, G., and Tanner, D.: Measurements of $\mathrm{OH}, \mathrm{HO}_{2}+\mathrm{RO}_{2}, \mathrm{H}_{2} \mathrm{SO}_{4}$, and MSA at the South Pole during ISCAT 2000, Atmos. Environ., 38, 5423-5437, doi:10.1016/j.atmosenv.2004.06.031, 2004.

Mayewski, P. A. and Dixon, D.: US International Trans Antarctic Scientific Expedition (US ITASE) glaciochemical data, Boulder, CO, USA, National Snow and Ice Data Center, 2005.

Mayewski, P. A., Spencer, M. J., Twickler, M. S., and Whitlow, S.: A glaciochemical survey of the Summit region, Greenland, Ann. Glaciol., 14, 186-190, 1990.

Mulvaney, R., Wagenbach, D., and Wolff, E. W.: Postdepositional change in snowpack nitrate from observation of year-round nearsurface snow in coastal Antarctica, J. Geophys. Res.-Atmos., 103, 11021-11031, doi:10.1029/97JD03624, 1998.

Nicolas, J. P. and Bromwich, D. H.: Climate of West Antarctica and Influence of Marine Air Intrusions, J. Climate, 24, 49-67, doi:10.1175/2010JCLI3522.1, 2011.

O'Driscoll, P., Minogue, N., Takenaka, N., and Sodeau, J.: Release of Nitric Oxide and Iodine to the Atmosphere from the Freezing of Sea-Salt Aerosol Components, J. Phys. Chem. A, 112, 16771682, doi:10.1021/jp710464c, 2012.

Oltmans, S. J., Johnson, B. J., and Helmig, D.: Episodes of high surface-ozone amounts at South Pole during summer and their impact on the long-term surface-ozone variation, Atmos. Environ., 42, 2804-2816, doi:10.1016/j.atmosenv.2007.01.020, 2008.

Oncley, S., Buhr, M., Lenschow, D., Davis, D., and Semmer, S.: Observations of summertime NO fluxes and boundary-layer height at the South Pole during ISCAT 2000 using scalar similarity, Atmos. Environ., 38, 5389-5398, doi:10.1016/j.atmosenv.2004.05.053, 2004.
Parish, T. R. and Bromwich, D. H.: Reexamination of the NearSurface Airflow over the Antarctic Continent and Implications on Atmospheric Circulations at High Southern Latitudes, Mon. Weather. Rev., 135, 1961-1973, doi:10.1175/MWR3374.1, 2007.

Preunkert, S., Ancellet, G., Legrand, M., Kukui, A., Kerbrat, M., Sarda-Estève, R., Gros, V., and Jourdain, B.: Oxidant Production over Antarctic Land and its Export (OPALE) project: An overview of the 2010-2011 summer campaign, J. Geophys. Res., 117, D15307, doi:10.1029/2011JD017145, 2012.

Reay, H. J., France, J. L., and King, M. D.: Decreased albedo, efolding depth and photolytic $\mathrm{OH}$ radical and $\mathrm{NO}_{2}$ production with increasing black carbon content in Arctic snow, J. Geophys. Res.-Atmos., 117, D00R20, doi:10.1029/2011JD016630, 2012.

Ridley, B., Walega, J., Montzka, D., Grahek, F., Atlas, E., Flocke, F., Stroud, V., Deary, J., Gallant, A., Boudries, H., Bottenheim, J., Anlauf, K., Worthy, D., Sumner, A., Splawn, B., and Shepson, P.: Is the Arctic surface layer a source and sink of $\mathrm{NO}_{\mathrm{x}}$ in winter/spring?, J. Atmos. Chem., 36, 1-22, doi:10.1023/A:1006301029874, 2000.

Rothlisberger, R., Hutterli, M., Sommer, S., Wolff, E., and Mulvaney, R.: Factors controlling nitrate in ice cores: Evidence from the Dome C deep ice core, J. Geophys. Res.-Atmos., 105, 2056520572, doi:10.1029/2000JD900264, 2000.

Rothlisberger, R., Hutterli, M., Wolff, E., Mulvaney, R., Fischer, H., Bigler, M., Goto-Azuma, K., Hansson, M., Ruth, U., Siggaard-Andersen, M., and Steffensen, J.: Nitrate in Greenland and Antarctic ice cores: a detailed description of post-depositional processes, Ann. Glaciol., 35, 209-216, doi:10.3189/172756402781817220, 2002.

Saiz-Lopez, A. and von Glasow, R.: Reactive halogen chemistry in the troposphere, Chem. Soc. Rev., 41, 6448-6472, doi:10.1039/c2cs35208g, 2012.

Saiz-Lopez, A., Mahajan, A. S., Salmon, R. A., Bauguitte, S. J. B., Jones, A. E., Roscoe, H. K., and Plane, J. M. C.: Boundary Layer Halogens in Coastal Antarctica, Science, 317, 348-351, doi:10.1126/science.1141408, 2007.

Sander, S., Friedl, R., Golden, D., Kurylo, M., Moortgat, G., KellerRudek, H., Wine, P., Kolb, C., Molina, M., Finlayson-Pitts, B., Huie, R., and Orkin, V.: Chemical kinetics and photochemical data for use in atmospheric studies, Evaluation number 15, JPL publication, 2006.

Schönhardt, A., Begoin, M., Richter, A., Wittrock, F., Kaleschke, L., Gómez Martín, J. C., and Burrows, J. P.: Simultaneous satellite observations of IO and BrO over Antarctica, Atmos. Chem. Phys., 12, 6565-6580, doi:10.5194/acp-12-6565-2012, 2012.

Seinfeld, J. H. and Pandis, S. N.: Atmospheric chemistry and physics: from air pollution to climate change, from air pollution to climate change, Wiley, 1998.

Sinclair, K. E., Bertler, N. A. N., Trompetter, W. J., and Baisden, W. T.: Seasonality of Airmass Pathways to Coastal Antarctica: Ramifications for Interpreting High-Resolution Ice Core Records, J. Climate, 26, 2065-2076, doi:10.1175/JCLI-D-12$00167.1,2013$.

Slusher, D., Huey, G., Tanner, D., Chen, G., Davis, D. D., Buhr, M., Nowak, J., Eisele, F., Kosciuch, E., Mauldin, L., Lefer, B., Shetter, R., and Dibb, J. E.: Measurements of pernitric acid at the South Pole during ISCAT 2000, Geophys. Res. Lett., 29, 2011, doi:10.1029/2002GL015703, 2002. 
Slusher, D. L., Neff, W. D., Kim, S., Huey, L. G., Wang, Y., Zeng, T., Tanner, D. J., Blake, D. R., Beyersdorf, A., Lefer, B. L., Crawford, J. H., Eisele, F. L., Mauldin, R. L., Kosciuch, E., Buhr, M. P., Wallace, H. W., and Davis, D. D.: Atmospheric chemistry results from the ANTCI 2005 Antarctic plateau airborne study, J. Geophys. Res.-Atmos., 115, D07304, doi:10.1029/2009JD012605, 2010.

Takenaka, N. and Bandow, H.: Chemical kinetics of reactions in the unfrozen solution of ice, J. Phys. Chem. A, 111, 8780-8786, doi:10.1021/jp0738356, 2007.

Thomas, J. L., Dibb, J. E., Huey, L. G., Liao, J., Tanner, D., Lefer, B., von Glasow, R., and Stutz, J.: Modeling chemistry in and above snow at Summit, Greenland - Part 2: Impact of snowpack chemistry on the oxidation capacity of the boundary layer, Atmos. Chem. Phys., 12, 6537-6554, doi:10.5194/acp-12-65372012, 2012.

Traversi, R., Becagli, S., Castellano, E., Cerri, O., Morganti, A., Severi, M., and Udisti, R.: Study of Dome C site (East Antartica) variability by comparing chemical stratigraphies, Microchem. J., 92, 7-14, doi:10.1016/j.microc.2008.08.007, 2009.
Wang, Y., Choi, Y., Zeng, T., Davis, D., Buhr, M., Huey, L. G., and Neff, W.: Assessing the photochemical impact of snow $\mathrm{NO}_{\mathrm{X}}$ emissions over Antarctica during ANTCI 2003, Atmos. Environ., 42, 2849-2863, doi:10.1016/j.atmosenv.2007.07.062, 2008.

Wolff, E. W., Jones, A. E., Bauguitte, S. J.-B., and Salmon, R. A.: The interpretation of spikes and trends in concentration of nitrate in polar ice cores, based on evidence from snow and atmospheric measurements, Atmos. Chem. Phys., 8, 5627-5634, doi:10.5194/acp-8-5627-2008, 2008.

Zatko, M. C., Grenfell, T. C., Alexander, B., Doherty, S. J., Thomas, J. L., and Yang, X.: The influence of snow grain size and impurities on the vertical profiles of actinic flux and associated $\mathrm{NO}_{\mathrm{x}}$ emissions on the Antarctic and Greenland ice sheets, Atmos. Chem. Phys., 13, 3547-3567, doi:10.5194/acp-13-35472013, 2013. 